\author{
東海・東南海・南海単独地震の応答に基づく \\ 三連動地震による超高層建物の最大值と累積值の応答評価法 \\ SEISMIC RESPONSE EVALUATION METHOD \\ FOR MAXIMUM RESPONSE AND CUMULATIVE DAMAGE OF HIGH-RISE BUILDING \\ UNDER THE TOKAI-TONANKAI-NANKAI MULTI-SEGMENT EARTHQUAKE \\ BASED ON THE RESPONSE OF THE EARTHQUAKES CONSTITUTING \\ THE MULTI-SEGMENT EARTHQUAKE
}

\author{
木 村暢志*, 北村春幸**, 佐藤利 昭 ${ }^{* * *}$, \\ 木村雄一 ${ }^{* * * *}$, 青野英志 ${ }^{* * * *}$, 山本 優 ${ }^{* * * * *}$ \\ Masashi KIMURA, Haruyuki KITAMURA, Toshiaki SATO, \\ Yuichi KIMURA, Hideshi AONO and Yu YAMAMOTO
}

\begin{abstract}
This paper examines relationship between Tokai-Tonankai-Nankai multi-segment earthquake and the earthquakes constituting it in the responses spectra and the energy spectra. Based on these relationships in the spectra, this paper proposes a seismic response evaluation method for maximum response and cumulative damage to Tokai-Tonankai-Nankai multi-segment earthquake of high-rise building. The maximum response is estimated by increasing the single ground motion to the level of the multi-segment earthquake before seismic response analysis. The cumulative damage is estimated by using energy balance. The proposed evaluation method is validated by comparing its results with those of seismic response analysis.
\end{abstract}

Keywords : Long-period ground motion, Tokai-Tonankai-Nankai multi-segment earthquake, High-rise building, Maximum response, Cumulative damage 長周期地震動, 東海・東南海・南海連動地震, 超高層建物, 最大応答, 累積損傷

1. はじめに

2003 年の十勝沖地震（ $\mathrm{M}_{\mathrm{w}} 8.0 ）$ を契機に注目を浴びた長周期地震 動は，地震観測網の拡大と共に調查研究が進み，地域毎に固有の長 周期の摇れが長時間続く地震動が想定されるようになった例えば 1)。 現在，それらの地震動による応答解析や実大実験で得られた知見を 踏まえ例えば 2)，超高層建物の設計には，層間変形角や塑性率に代表 される建物応答の最大值に加え, 塑性歪エネルギーや累積塑性変形 倍率などの累積值に対する耐震安全性の判定が要求されている ${ }^{3)}$ 。

2011 年の東北地方太平洋沖地震では, 想定を上回る $\mathrm{M}_{\mathrm{w}} 9.0$ の巨 大地震が発生した。これを受け，南海トラフで発生する巨大地震で は，これまでに検討されてきた東海・東南海・南海地震の三連動地 震に加え, M 9 クラスの四連動地震が検討され始め ${ }^{4)}$, 現在までに 首都圈, 名古屋地区, 大阪地区における連動地震の予測波が提示さ れている例えば5), 6)。これらの計算は, 連動地震を構成する地震の震 源モデルの破壞開始時刻をずらしたもので, 個々の地震から発生す る地震動を重放合わせる方法に基づいている。したがって, 連動地 震は，個々の地震の震源モデルや破壊開始点が共通でも，発生する 順序や破壞開始時刻の差異によって様々な連動地震が想定され，地 点毎に予測される地震動も膨大な数となる。そのため, 何らかの方
法で連動地震の平均的なレベルとばらつき幅を把握し，連動地震に よる超高層建物の応答をある程度の範囲で想定できることが望まれ ている。

複数の地震動による超高層建物の応答評価として, 北村らは名古 屋三の丸地区を対象に, 海溝型地震や直下地震による 3 つの予測波 が単独で入力した場合と，それらを時系列に並べた地震動群が入力 した場合について，応答解析に基づく検討を行っている。この結果 より，複数の地震動が時間を空けて発生した場合，建物応答の最大 值が単独で応答が最大となる地震動に支配され，入力エネルギーが すべての地震動の累積值となることを示し, 地震動を単独に入力し た応答解析の結果から，連続入力時の最大值や累積值を予測する手 法と複数の地震動に対する耐震性能の評価方法を提案している7)。

本論文は, 山本・吉村が 3 次元大規模 FEM により計算した東 海・東南海・南海連動地震（以下，三連動地震と呼ぶ）における, 首都圈, 名古屋地区, 大阪地区の予測波 ${ }^{5)}$ 対象に, 三連動地震を 構成する 3 つの地震（以下，単独地震と呼ぶ）による応答から，三 連動地震による超高層建物の応答を想定することを目的とする。三 連動地震発生時には, 堆積平野の深い地下構造に依存する周期帯域 (「特定の周期帯」3) と呼ぶ）で地震動が増幅され，その周期帯域に

\footnotetext{
* 東京理科大学大学院理工学研究科建築学専攻 大学院生

** 東京理科大学理工学部建築学科 教授·博士 (工学)

$* * *$ 東京理科大学理工学部建築学科 助教 $\cdot$ 博士 (工学)

$* * * *$ 大成建設 (株) 設計本部 修士 (工学)

***** 大成建設 (株) 技術センター 博士(工学)
}

Graduate Student, Dept of Architecture, Tokyo Univ of Science.

Prof., Dept. of Architecture, Tokyo Univ. of Science, Dr. Eng.

Assist. Prof., Dept. of Architecture, Tokyo Univ. of Science, Dr. Eng.

Design and Proposal Division, Taisei Corporation, M. Eng.

Technology Center, Taisei Corporation, Dr. Eng. 
固有周期を持つ超高層建物が大きく摇れることが確認されている ${ }^{8)}$ 本論文では, この性質に基づき, 単独地震の予測波によるエネルギ ースペクトルを用いて, 各地点で検討対象とする「特定の周期帯」 を設定する。この周期帯域におけりる地震動の入力エネルギーが最大 となる方向を主軸と定め, 検討に用いる地震動とする。

本論文は, 次のように構成されている。まず, 単独地震による建 物応答から三連動地震による応答を想定するため, それらの対応関 係を 1 質点弾性減衰系の応答である応答スペクトルとエネルギー スペクトルを用いて明らかにする。既往研究より, 単独地震が互い に干渉せずに一定間隔を保って発生した場合，その応答スペクトル は最大の単独地震を包絡するスペクトルで表されるが 7), 単独地震 による地震動が相互に干渉し合う場合には, それらが合成され, 単 独地震の応答スペクトルを上回ることがある。ここでは連動地震に おいて, 単独地震相互の位相差に不確定性があることを踏まえ, 三 連動地震の応答スペクトルを, それを構成する単独地震の応答スペ クトルの二乗和平方根 (SRSS) として評価する。また, 三連動地震 のエネルギースペクトルは, それを構成する 3 つの単独地震による 入力エネルギーの水平 2 成分の総和で評価する。これらを三連動地 震の予測波による計算結果と比較し, 三連動地震時の最大応答が 3 つの単独地震の応答スペクトルのSRSS, 累積值が 3 つの単独地震 の入力エネルギーの総和で想定されることを検証する ${ }^{9}$ 。

続いて，これらの考え方を多質点弾塑性系に拡張する。構造物が 塑性化を伴う場合, 特定層への損傷集中が無視できないため, ここ では単独地震による時刻歷応答解析の結果から, 三連動地震時の応 答を評価する方法を提案する。1 質点弾性減衰系と同様, 単独地震 の SRSS を三連動地震の応答スペクトルとした上で, SRSS と単独 地震のスペクトルの平均值から比率 $a_{k}$ を求め, それを単独地震に 乗じた結果を三連動地震の予測波として最大応答を評価する ${ }^{10)}$ 。累 積值は, 時刻歴応答解析の結果に加え, エネルギーの釣合に基づく 応答評価 ${ }^{11)}$, 12) の考え方を導入し, 建物各部へのエネルギー配分を 評価する。最終的には, 各地点で検討対象とした「特定の周期帯」 に固有周期がある超高層建物を設定し, 本論文で述べた応答評価法 による結果と, 三連動地震の予測波による時刻歷応答解析の結果を 比較することで，評価法の妥当性を検証する。

\section{2. 検討対象地震動の概要}

\section{1 地震発生ケースと検討地点}

本論文では，山本・吉村が中央防災会議の 2003 年震源モデル ${ }^{1)}$ に基づき， 3 次元大規模 FEM による東海・東南海・南海連動地震 のシミュレーション解析により評価した予測波 ${ }^{5)}$ を対象に議論を 進める。モデル化の領域は, 関東から四国沖に至る $864 \mathrm{~km} \times 300 \mathrm{~km}$, 深さ $50 \mathrm{~km}$ であり, 解析地震波は周期 $2.5 \mathrm{~s}$ 以上が適用範囲となって いる。本論文では, 実在構造物の固有周期を考慮して, 検討対象と する周期範囲を $2.5 \sim 10.0 \mathrm{~s}$ と定める。

地震発生ケースが異なる 2 種類の三連動地震を対象とし, 紀伊半 島沖を破壊開始点として, 南海地震が西へ, 東南海地震と東海地震 が東へ破壞が伝播する中央防災会議モデルを Case-1, 破壊開始点を 南海地震西端の足摺岬沖として, 南海地震, 東南海地震, 東海地震 の順に伝播する東京への影響が大きい場合を Case-2 とする。すなわ ち, 東海地震と東南海地震の震源モデルは, 地震発生ケースによら
ず同一で, 南海地震の震源モデルのみ, 破壊開始点を Case-1 で紀伊 半島沖に, Case-2 で足摺岬沖に設定してある。Table1 に対象とする 地震とその略称を，Table2 に検討地点とその略称をまとめる。検討 対象地域は, 大阪平野, 濃尾平野, 関東平野の 3 地域で, 連動地震 の予測波のばらつきを考慮して, それぞれの平野から各 4 地点, 合 計 12 地点を選定して以降の検討を進める。

Table1 Assumed earthquakes Table2 Study sites

\begin{tabular}{|c|c|}
\hline Assumed Earthquake & Abbreviation \\
\hline \hline Tokai Earthquake & $\mathrm{T}$ \\
\hline Tonankai Earthquake & $\mathrm{TN}$ \\
\hline $\begin{array}{c}\text { Nankai Earthquake } \\
\text { (Case-1) }\end{array}$ & $\mathrm{N} \_1$ \\
\hline $\begin{array}{c}\text { Nankai Earthquake } \\
\text { (Case-2) }\end{array}$ & $\mathrm{N} \_2$ \\
\hline $\begin{array}{c}\text { Tokai-Tonankai-Nankai } \\
\text { Multi-segment Earthquake } \\
\text { (Case-1) }\end{array}$ & T-TN-N_1 \\
\hline $\begin{array}{c}\text { Tokai-Tonankai-Nankai } \\
\text { Multi-segment Earthquake } \\
\text { (Case-2) }\end{array}$ & T-TN-N_2 \\
\hline
\end{tabular}

\begin{tabular}{|c|c|c|}
\hline \multicolumn{2}{|c|}{ Study Site } & Abbreviation \\
\hline \hline \multirow{4}{*}{ Osaka } & Klaik-net Konohana & OSKH \\
\cline { 2 - 3 } & Osaka City Hall & OSOS2 \\
\cline { 2 - 3 } & Osaka Prefectural Government & OSOS \\
\cline { 2 - 3 } Nobi & Yao City Hall & OSYO \\
\cline { 2 - 3 } Plain & Yokkaichi City Hall & MIYK \\
\cline { 2 - 3 } & Tokoname City Hall & AITK \\
\cline { 2 - 3 } & Nagoya City Hall & AING \\
\hline \multirow{3}{*}{ Kanto } & Minami Chita Town Hall & AIMT \\
\cline { 2 - 3 } Plain & Kuki City Hall & SIKK \\
\cline { 2 - 3 } & Tokyo Metropolitan Government & TKTK \\
\cline { 2 - 3 } & Noda City Hall & CBND \\
\hline
\end{tabular}

\section{2 特定の周期帯の設定}

長周期地震動は，堆積平野の深い地下構造に依存する「特定の周 期帯」で増幅されるため, 固有周期がそれらの周期帯域にある超高 層建物の応答が特に問題視されている ${ }^{8)}$ 。本節ではこれら「特定の 周期帯」を，各地点での予測波に対する分析を通して設定する。分 析では，各地点に固有の特性を抽出するため，直交する水平 2 成分 の入力エネルギーの合計值が，検討方向の選び方によらず一定值と なる関係を踏まえ，Fig.1 に示すように，次の手順で対象とする 12 地点の「特定の周期帯」を検討する。

(1)予測波の NS・EW 成分から入力エネルギーを求め, その和 $\left(E=E_{N S}+E_{E W}\right)$ の速度換算值 $V_{E}(=\sqrt{2 E / M}, M$ : 質量 $)$ か ら, 水平 2 成分のエネルギースペクトルを評価する。

(2)各地点の予測波について，検討対象周期である $2.5 \sim 10.0 \mathrm{~s}$ にお ける $V_{E}$ の平均值 $\bar{V}_{E, 2.5-10}$ を求め, $V_{E}$ が $\bar{V}_{E, 2.5-10}$ を上回る周期帯 域を $T_{L}-T_{H}$ とし, その範囲における $V_{E}$ の平均值 ${ }_{P} \bar{V}_{E}$ を計算する。 (3)各地点で ${ }_{P} \bar{V}_{E}$ が最大となる単独地震を選定し, 単独地震と三連 動地震の周期帯域 $T_{L}-T_{H}$ の対応関係を調心゙る。

Table3 には，地震発生ケース Case-1 と Case-2 の 12 地点に対す る計算結果として, 周期 $2.5 \sim 10.0 \mathrm{~s}$ における $V_{E}$ の平均值 $\bar{V}_{E, 2.5-10}$, $\bar{V}_{E, 2.5-10}$ より定めた周期帯域 $T_{L}-T_{H}$ を規定する周期 $T_{L}$ と $T_{H}, T_{L}-T_{H}$ における $V_{E}$ の平均值 ${ }_{P} \bar{V}_{E}$ を一覧にして示してある。同表では，地 震発生ケースごとに「特定の周期帯」を網掛けで示すため, Case-1 と Case-2 の両方に東海地震 $\mathrm{T}$ と東南海地震 TN の值を記述している。 また, Fig.2 には, 代表地点として OSKH, CBMTを取り出し, 三 連動地震とそれを構成する東海地震，東南海地震，南海地震の周期 帯域 $T_{L}-T_{H}$ の関係を図示してある。同図は, 周期帯域 $T_{L}-T_{H}$ におけ る平均值 ${ }_{P} \bar{V}_{E}$ を縦軸としたもので, 一部の予測波では $V_{E}$ が $\bar{V}_{E, 2.5-10}$ を上回る周期帯域で分割されるため, 2 つの区間が表示し てある。

Fig.2 より, 設定した周期带域 $T_{L}-T_{H}$ は, 地震発生ケースによらず, 三連動地震と ${ }_{P} \bar{V}_{E}$ 值が大きい単独地震, 具体的には OSKH の南海 
地震と CBMT の東海地震で, 三連動地震と概ね同じ範囲を示して いる。Table3 に示す通り, この傾向は他の 10 地点でも確認され, 大 阪平野で南海地震, 濃尾平野で東南海地震, 関東平野で東海地震が 他の単独地震よりも ${ }_{P} \bar{V}_{E}$ が大きい。このように応答レベルが大きな 単独地震は, 三連動地震と $T_{L}-T_{H}$ が良好な対応関係にある。以上を 踏まえ, 大阪平野で南海地震, 濃尾平野で東南海地震, 関東平野で 東海地震を最大単独地震と呼ぶこととし, これら最大単独地震より 定めた $T_{L}-T_{H}$ を, 各地点での「特定の周期帯」とする。Table3 の網 掛部分は，この設定に基づく各地点での「特定の周期帯」である。

この設定方法について, Table3(c)に示す CBND (Case-2) と CBMT (Case-2) に着目すると, 関東平野の最大単独地震とした東海地震よ りも, 南海地震の ${ }_{P} \bar{V}_{E}$ が例外的に大きいことが分かる。地震発生ケ
ース Case-2 では, 南海地震西端の足摺岬沖を破壊開始点とするため, 関東平野に向から方向之破壊伝播方向が一致する。したがって，南 海地震の影響が増大した要因は, ディレクティビティ効果と考えら れる。このように地震発生ケースによって, 先に述べた各平野と対 応する地震が，必ずしも最大単独地震と一致するわけではない。し かし，本論文では想定される様々な連動地震の平均的なレベルとば らつき幅を把握することを目的とするため，ここで取り上げた Case-2 の CBND と CBMT は, 以降の検討でも東海地震の周期带域 $T_{L}-T_{H}$ を「特定の周期帯」とし，この設定が建物応答に与える影響を 調べていくことにする。

\section{3 長周期地震動の主軸の設定}

「特定の周期帯」は, 水平 2 成分の入力エネルギーの和よりエネ

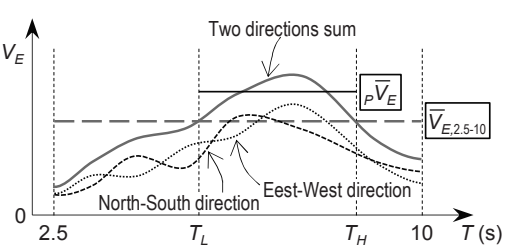

Fig.1 Procedure for setting of dominant period range

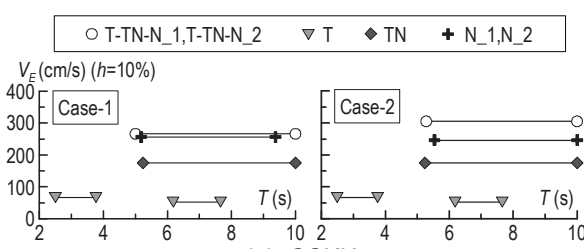

(a) OSKH

Fig.2 Average energy spectra and dominant period range of Tokai, Tonankai, Nankai and the multi-segment earthquake

Table3 Average energy spectra and dominant period range of Tokai, Tonankai, Nankai and the multi-segment earthquake at each site (a) Osaka Plain

\begin{tabular}{|c|c|c|c|c|c|c|c|c|c|c|c|}
\hline Site & Earthquake & $\begin{array}{l}\bar{V}_{E, 2 S-10} \\
(\mathrm{~cm} / \mathrm{s})\end{array}$ & $\begin{array}{l}T_{L} \\
(\mathrm{~s})\end{array}$ & $\begin{array}{l}T_{H} \\
\text { (s) }\end{array}$ & $\begin{array}{c}{ }_{P} \bar{V}_{E} \\
(\mathrm{~cm} / \mathrm{s})\end{array}$ & Site & Earthquake & $\begin{array}{l}\bar{V}_{E, 25-10} \\
(\mathrm{~cm} / \mathrm{s})\end{array}$ & $\begin{array}{l}T_{L} \\
(\mathrm{~s})\end{array}$ & $\begin{array}{l}T_{H} \\
\text { (s) }\end{array}$ & $\begin{array}{c}{ }_{P} \bar{V}_{E} \\
(\mathrm{~cm} / \mathrm{s})\end{array}$ \\
\hline \multirow{5}{*}{$\begin{array}{c}\text { OSKH } \\
\text { (Case-1) }\end{array}$} & \multirow{2}{*}{$\mathrm{T}$} & \multirow{2}{*}{49.4} & 2.50 & 3.76 & 66.7 & \multirow{5}{*}{$\begin{array}{l}\text { MIYK } \\
\text { (Case-1) }\end{array}$} & $\mathrm{T}$ & 84.6 & 2.50 & 4.32 & 113.0 \\
\hline & & & 6.18 & 7.66 & 52.6 & & \multirow{2}{*}{$\mathrm{TN}$} & \multirow{2}{*}{450.0} & 2.76 & 3.22 & 468.7 \\
\hline & $\mathrm{TN}$ & 152.7 & 5.24 & 10.00 & 175.3 & & & & 5.48 & 8.48 & 531.9 \\
\hline & $\mathrm{N} \_1$ & 219.2 & 5.18 & 9.38 & 256.3 & & $\mathrm{~N} \_1$ & 182.9 & 5.20 & 9.12 & 233.6 \\
\hline & T-TN-N_1 & 240.3 & 5.00 & 10.00 & 266.1 & & T-TN-N_1 & 514.1 & 5.52 & 8.70 & 611.5 \\
\hline \multirow{5}{*}{$\begin{array}{c}\text { OSKH } \\
\text { (Case-2) }\end{array}$} & T & & 2.50 & 3.76 & 66.7 & \multirow{6}{*}{$\begin{array}{l}\text { MIYK } \\
\text { (Case-2) }\end{array}$} & $\mathrm{T}$ & 84.6 & 2.50 & 4.32 & 113.0 \\
\hline & & 49.4 & 6.18 & 7.66 & 52.6 & & \multirow{2}{*}{$\mathrm{TN}$} & \multirow{2}{*}{450.0} & 2.76 & 3.22 & 468.7 \\
\hline & $\mathrm{TN}$ & 152.7 & 5.24 & 10.00 & 175.3 & & & & 5.48 & 8.48 & 531.9 \\
\hline & $\mathrm{N} \_2$ & 192.2 & 5.54 & 10.00 & 246.1 & & $\mathrm{~N} \_2$ & 256.6 & 4.80 & 8.46 & 327.6 \\
\hline & T-TN-N_2 & 255.5 & 5.28 & 10.00 & 304.9 & & T-TN-N 2 & 4943 & 2.78 & 3.22 & 517.1 \\
\hline \multirow{6}{*}{$\begin{array}{c}\text { OSOS2 } \\
\text { (Case-1) }\end{array}$} & T & 37.9 & 2.50 & 3.82 & 55.6 & & & 494.3 & 5.32 & 8.12 & 600.0 \\
\hline & & & 6.36 & 7.18 & 38.7 & \multirow{4}{*}{$\begin{array}{c}\text { AITK } \\
\text { (Case-1) }\end{array}$} & $\mathrm{T}$ & 69.1 & 2.50 & 6.32 & 83.6 \\
\hline & & & 2.70 & 3.22 & 152.6 & & $\mathrm{TN}$ & 221.3 & 4.16 & 7.12 & 264.3 \\
\hline & TN & 138.9 & 5.12 & 9.40 & 152.1 & & $\mathrm{~N} \_1$ & 80.9 & 3.30 & 8.06 & 88.5 \\
\hline & $\mathrm{N} \_1$ & 197.3 & 4.62 & 8.92 & 230.9 & & T-TN-N 1 & 242.4 & 4.12 & 6.96 & 281.5 \\
\hline & T-TN-N_1 & 268.3 & 4.78 & 9.24 & 310.6 & \multirow{4}{*}{$\begin{array}{c}\text { AITK } \\
\text { (Case-2) }\end{array}$} & $\mathrm{T}$ & 69.1 & 2.50 & 6.32 & 83.6 \\
\hline \multirow{6}{*}{$\begin{array}{c}\text { OSOS2 } \\
\text { (Case-2) }\end{array}$} & & 37.9 & 2.50 & 3.82 & 55.6 & & $\mathrm{TN}$ & 221.3 & 4.16 & 7.12 & 264.3 \\
\hline & \multirow[b]{2}{*}{ TN } & 37.9 & 6.36 & 7.18 & 38.7 & & $\mathrm{~N} \_2$ & 161.4 & 4.32 & 7.36 & 200.3 \\
\hline & & \multirow{2}{*}{138.9} & 2.70 & 3.22 & 152.6 & & T-TN-N_2 & 323.4 & 4.36 & 7.42 & 401.1 \\
\hline & & & 5.12 & 9.40 & 152.1 & \multirow{5}{*}{$\begin{array}{c}\text { AING } \\
\text { (Case-1) }\end{array}$} & $T$ & 41.6 & 2.50 & 4.68 & 70.9 \\
\hline & N_2 & 169.6 & 5.76 & 10.00 & 217.0 & & TN & 131.8 & 2.50 & 4.30 & 212.7 \\
\hline & T-TN-N_2 & 219.5 & 5.74 & 9.94 & 260.2 & & & & 2.90 & 3.66 & 56.8 \\
\hline \multirow{4}{*}{$\begin{array}{c}\text { OSOS } \\
\text { (Case-1) }\end{array}$} & $\mathrm{T}$ & 23.4 & 2.50 & 4.14 & 30.8 & & $N_{-} I_{1}$ & 53.1 & 5.84 & 9.12 & 57.8 \\
\hline & $\mathrm{TN}$ & 85.9 & 6.24 & 10.00 & 103.2 & & T-TN-N_1 & 145.7 & 2.50 & 4.32 & 224.5 \\
\hline & N_1 & 128.2 & 6.00 & 10.00 & 145.5 & \multirow{4}{*}{$\begin{array}{c}\text { AING } \\
(\text { Case-2) }\end{array}$} & $\mathrm{T}$ & 41.6 & 2.50 & 4.68 & 70.9 \\
\hline & T-TN-N_1 & 182.2 & 6.06 & 10.00 & 215.6 & & TN & 131.8 & 2.50 & 4.30 & 212.7 \\
\hline \multirow{4}{*}{$\begin{array}{c}\text { OSOS } \\
\text { (Case-2) }\end{array}$} & $\mathrm{T}$ & 23.4 & 2.50 & 4.14 & 30.8 & & $\mathrm{~N} \_2$ & 88.0 & 5.08 & 10.00 & 98.3 \\
\hline & $\mathrm{TN}$ & 85.9 & 6.24 & 10.00 & 103.2 & & T-TN-N_2 & 157.8 & 2.50 & 4.24 & 233.6 \\
\hline & N_2 & 119.0 & 6.24 & 10.00 & 151.3 & \multirow{6}{*}{$\begin{array}{c}\text { AIMT } \\
\text { (Case-1) }\end{array}$} & $\mathrm{T}$ & 66.1 & 2.50 & 6.06 & 88.3 \\
\hline & T-TN-N_2 & 148.1 & 6.28 & 10.00 & 185.1 & & \multirow{2}{*}{$\mathrm{TN}$} & 2554 & 3.34 & 6.66 & 283.3 \\
\hline \multirow{5}{*}{$\begin{array}{c}\text { OSYO } \\
\text { (Case-1) }\end{array}$} & T & 34.0 & 2.50 & 3.82 & 45.4 & & & 2030.4 & 9.20 & 10.00 & 262.8 \\
\hline & & & 4.58 & 6.82 & 35.6 & & $\mathrm{~N} \_1$ & 70.1 & 3.64 & 8.06 & 80.7 \\
\hline & $\mathrm{TN}$ & 103.8 & 5.14 & 9.86 & 115.8 & & T-TN-N 1 & & 3.30 & 6.68 & 307.3 \\
\hline & $\mathrm{N} \_1$ & 265.9 & 4.56 & 8.02 & 362.5 & & $1-1 N-N_{-} 1$ & 270.1 & 9.52 & 10.00 & 279.4 \\
\hline & T-TN-N_1 & 295.5 & 4.68 & 8.80 & 369.0 & & $\mathrm{~T}$ & 66.1 & 2.50 & 6.06 & 88.3 \\
\hline & T & 340 & 2.50 & 3.82 & 45.4 & & TN & 2554 & 3.34 & 6.66 & 283.3 \\
\hline & 1 & 34.0 & 4.58 & 6.82 & 35.6 & AIMT & $1 \mathrm{~N}$ & & 9.20 & 10.00 & 262.8 \\
\hline (Case-2) & TN & 103.8 & 5.14 & 9.86 & 115.8 & (Case-2) & $\mathrm{N} \_2$ & 143.2 & 3.50 & 7.00 & 169.3 \\
\hline & $\mathrm{N} \_2$ & 269.4 & 4.84 & 8.34 & 374.6 & & T-TN- & & 3.24 & 6.04 & 317.2 \\
\hline & T-TN-N 2 & 294.0 & 4.82 & 8.42 & 392.2 & & $1-1 N-1 N_{2}$ & 210.5 & 9.54 & 10.00 & 281.3 \\
\hline
\end{tabular}

(c) Kanto Plain

\begin{tabular}{|c|c|c|c|c|c|}
\hline Site & Earthquake & $\begin{array}{l}\bar{V}_{E, 25-10} \\
(\mathrm{~cm} / \mathrm{s})\end{array}$ & $\begin{array}{l}T_{L} \\
(\mathrm{~s}) \\
\end{array}$ & $\begin{array}{r}T_{H} \\
(\mathrm{~s}) \\
\end{array}$ & $\begin{array}{l}{ }_{P} \bar{V}_{E} \\
(\mathrm{~cm} / \mathrm{s})\end{array}$ \\
\hline \multirow{6}{*}{$\begin{array}{c}\text { SIKK } \\
\text { (Case-1) }\end{array}$} & $\mathrm{T}$ & 154.2 & 3.34 & 6.00 & 174.9 \\
\hline & $\mathrm{TN}$ & 114.7 & 5.74 & 9.36 & 133.5 \\
\hline & \multirow{2}{*}{ N_1 } & \multirow{2}{*}{60.3} & 5.02 & 8.92 & 72.4 \\
\hline & & & 9.54 & 10.00 & 61.7 \\
\hline & \multirow{2}{*}{ T-TN-N_1 } & \multirow{2}{*}{204.5} & 3.66 & 4.18 & 205.7 \\
\hline & & & 4.34 & 9.16 & 213.6 \\
\hline \multirow{6}{*}{$\begin{array}{c}\text { SIKK } \\
\text { (Case-2) }\end{array}$} & $\mathrm{T}$ & 154.2 & 3.34 & 6.00 & 174.9 \\
\hline & $\mathrm{TN}$ & \begin{tabular}{ll|}
114.7 \\
\end{tabular} & 5.74 & 9.36 & 133.5 \\
\hline & \multirow{2}{*}{$\mathrm{N} \_2$} & \multirow{2}{*}{145.4} & 4.74 & 8.12 & $\begin{array}{l}173.7 \\
\end{array}$ \\
\hline & & & 8.64 & 10.00 & 155.1 \\
\hline & \multirow{2}{*}{ T-TN-N_2 } & \multirow{2}{*}{223.0} & 3.46 & 6.46 & 250.5 \\
\hline & & & 9.80 & 10.00 & 225.2 \\
\hline \multirow{7}{*}{$\begin{array}{c}\text { TKTK } \\
\text { (Case-1) }\end{array}$} & $\mathrm{T}$ & 189.0 & 6.64 & 10.00 & 225.1 \\
\hline & \multirow{2}{*}{$\mathrm{TN}$} & \multirow{2}{*}{96.5} & 2.80 & 4.96 & 107.6 \\
\hline & & & 5.24 & 6.92 & 98.4 \\
\hline & $\mathrm{N} \_1$ & 49.5 & 5.52 & 10.00 & 56.8 \\
\hline & \multirow{3}{*}{ T-TN-N_1 } & \multirow{3}{*}{218.8} & 3.02 & 3.16 & 219.3 \\
\hline & & & 4.00 & 4.28 & 221.3 \\
\hline & & & 6.76 & 10.00 & $\begin{array}{l}237.8 \\
\end{array}$ \\
\hline \multirow{6}{*}{$\begin{array}{l}\text { TKTK } \\
\text { (Case-2) }\end{array}$} & $\mathrm{T}$ & 189.0 & 6.64 & 10.00 & 225.1 \\
\hline & \multirow{2}{*}{$\mathrm{TN}$} & \multirow{2}{*}{96.5} & 2.80 & 4.96 & 107.6 \\
\hline & & & 5.24 & 6.92 & 98.4 \\
\hline & $\mathrm{N} \_2$ & 122.2 & 4.30 & 10.00 & 136.6 \\
\hline & \multirow{2}{*}{ T-TN-N_2 } & \multirow{2}{*}{241.4} & 4.30 & 4.98 & 243.8 \\
\hline & & & 6.24 & 9.20 & 257.6 \\
\hline \multirow{4}{*}{$\begin{array}{l}\text { CBND } \\
\text { (Case-1) }\end{array}$} & $\bar{T}$ & 155.7 & 3.60 & 6.56 & 200.3 \\
\hline & TN & 86.7 & 2.68 & 7.16 & 101.1 \\
\hline & $\mathrm{N} \_1$ & 52.1 & 4.38 & 8.08 & 65.9 \\
\hline & T-TN-N_1 & 186.5 & 3.78 & 6.88 & 233.7 \\
\hline \multirow{4}{*}{$\begin{array}{l}\text { CBND } \\
\text { (Case-2) }\end{array}$} & $\mathrm{T}$ & 155.7 & 3.60 & 6.56 & 200.3 \\
\hline & $\mathrm{TN}$ & 86.7 & 2.68 & 7.16 & 101.1 \\
\hline & N_2 & 154.1 & 4.52 & 7.54 & 223.5 \\
\hline & T-TN-N_2 & 216.9 & 3.90 & 7.10 & 284.6 \\
\hline \multirow{5}{*}{$\begin{array}{c}\text { CBMT } \\
\text { (Case-1) }\end{array}$} & \multirow{2}{*}{$\mathrm{T}$} & & 4.00 & 4.72 & 203.2 \\
\hline & & 196.1 & 6.04 & 8.88 & 221.0 \\
\hline & $\mathrm{TN}$ & \begin{tabular}{ll|}
138.3 \\
\end{tabular} & 5.00 & 8.00 & 178.8 \\
\hline & $\mathrm{N} \_1$ & 69.6 & 4.86 & 8.54 & 88.4 \\
\hline & T-TN-N_1 & 256.0 & 5.28 & 8.56 & 300.0 \\
\hline & $T$ & 196.1 & 4.00 & 4.72 & 203.2 \\
\hline & & & 6.04 & 8.88 & 221.0 \\
\hline $\begin{array}{l}\text { CBMT } \\
\text { (Cage-2 }\end{array}$ & $\mathrm{TN}$ & 138.3 & 5.00 & 8.00 & 178.8 \\
\hline & $\mathrm{N} \_2$ & 220.1 & 4.80 & 7.98 & 314.2 \\
\hline & T-TN-N_2 & 305.2 & 5.12 & 8.28 & 378.6 \\
\hline
\end{tabular}


ルギースペクトルを評価することで設定した。一方, 建物応答の最 大值を考える場合, 検討地点毎に地震動を定める必要がある。ここ では，まず各地点の予測波の NS・EW 成分を 15 度ピッチに合成し， 「特定の周期帯」におけるエネルギースペクトルの平均值 $\bar{V}_{E}$ と, 擬 似速度応答スペクトルの平均值 ${ }_{p} \bar{S}_{V}$ から地震動の方向性を調べる。

計算結果として, Fig.3 に 12 地点における三連動地震と単独地 震のエネルギースペクトルの平均值 $\bar{V}_{E}(h=10 \%)$ と応答スペクトル の平均值 ${ }_{p} \bar{S}_{V}(h=5 \%)$ を平面分布にして示寸。同図は, 縦軸を NS
方向, 横軸を $\mathrm{EW}$ 方向と対応させたもので, 予測波毎に $\bar{V}_{E}$ と ${ }_{p} \bar{S}_{V}$ が 最大となった方向を主軸として線分で表示してある。同図(a)，(b) は，それぞれ地震発生ケース Case-1，2 に対する計算結果で，図中 には四国沖から駿河湾にかけての震源モデルのアスペリティと背景 領域を濃淡に色分けして示寸と共に，破壊開始点を々印，各予測波 の検討地点をの印で示してある。

Fig.3 に示した計算結果について, 検討地点毎に各予測波のエネル ギースペクトルと擬似速度応答スペクトルの平均值 $\bar{V}_{E},{ }_{p} \bar{S}_{V}$ の対

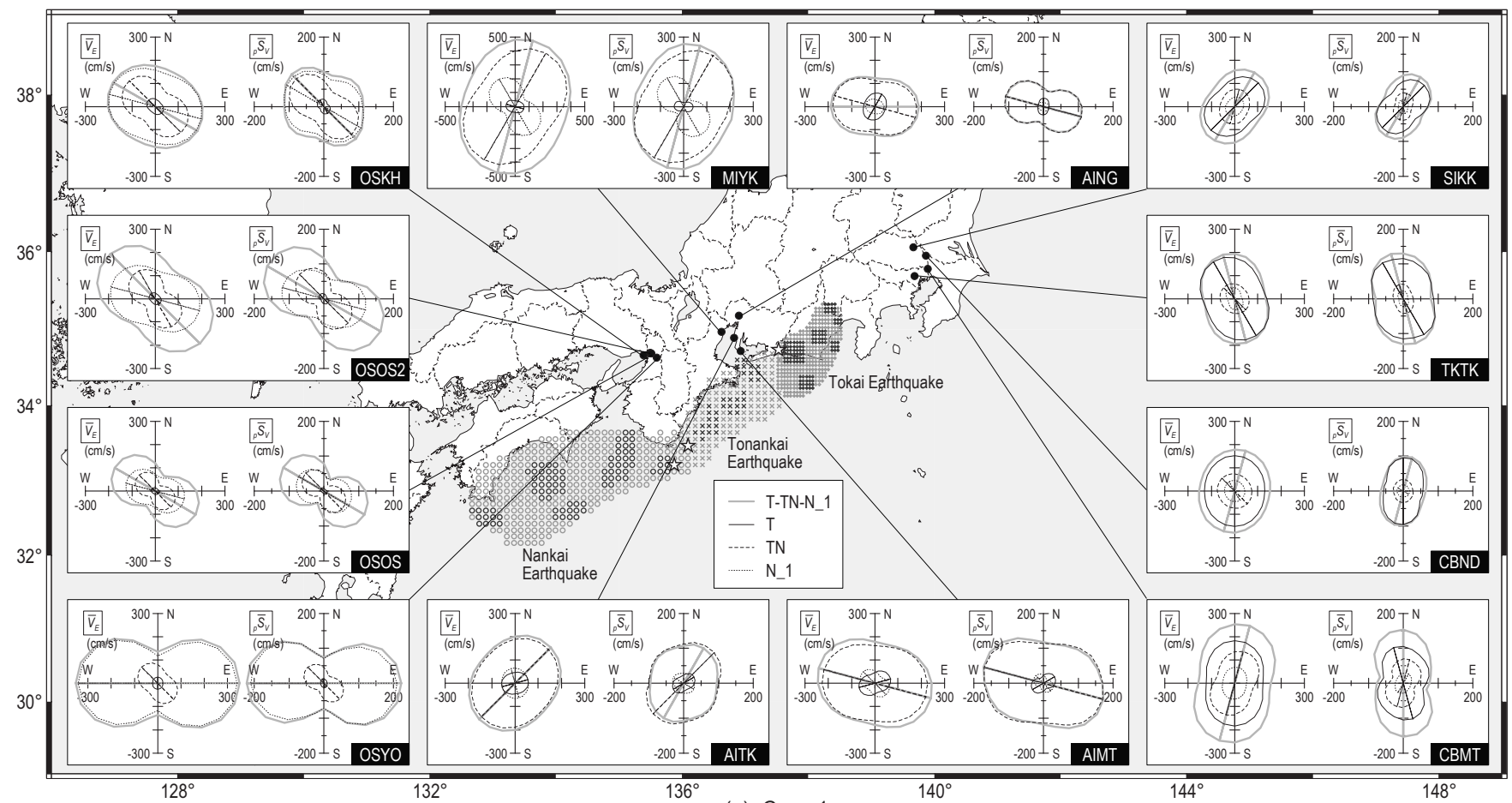

(a) Case-1

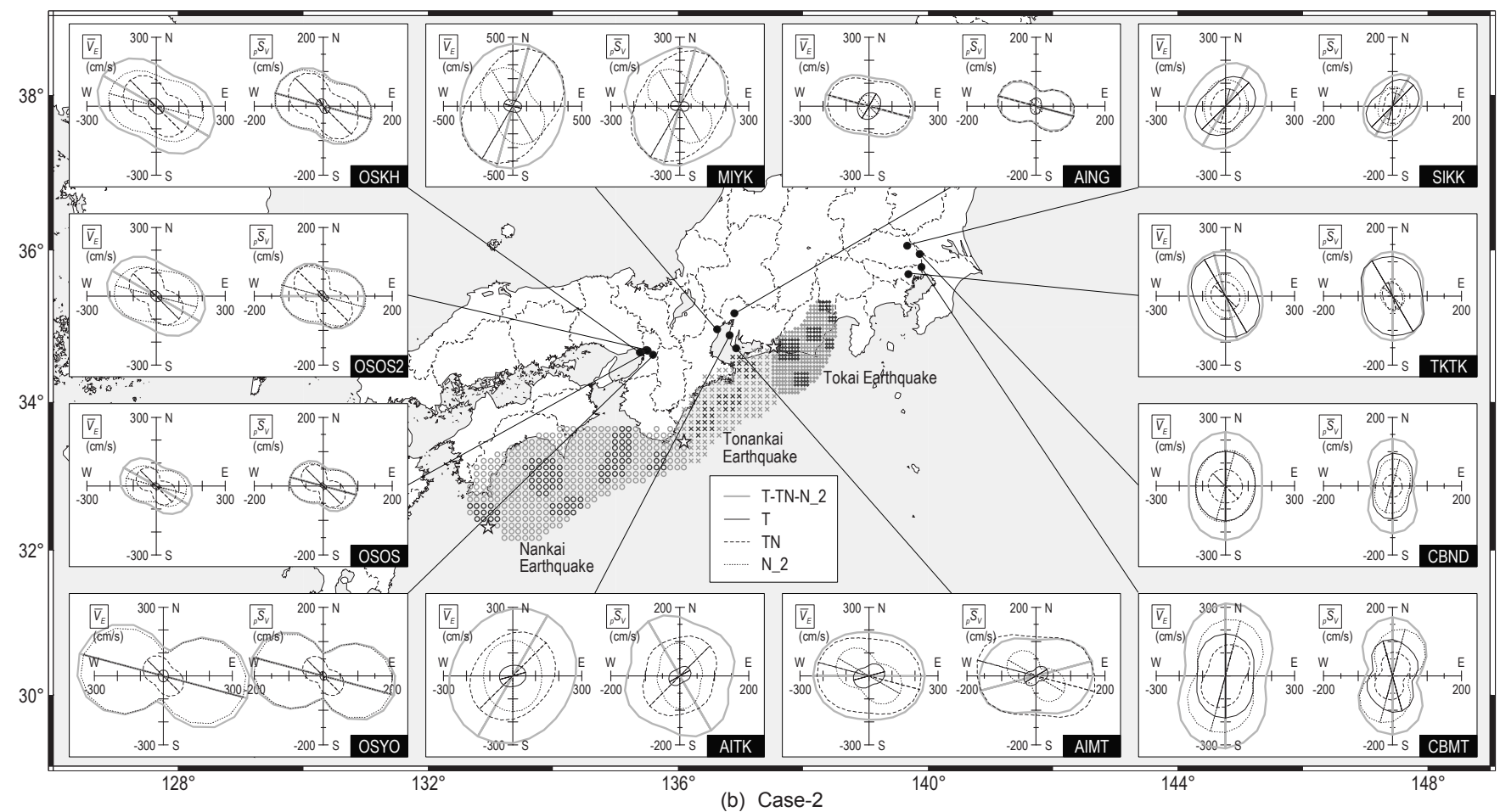

Fig.3 Distribution in the horizontal plane of average energy spectra $(h=10 \%)$ and average pseudo-velocity response spectra $(h=5 \%)$ at each site 
応関係を見ると, 地点によって平面分布に相違が認められるが，両 者の主軸方向は AITK の Case-2 を除き, 30 度以下の範囲にあること が分かる。続いて三連動地震と先に述べた最大単独地震の主軸方向 の対応関係として, まず $\bar{V}_{E}$ に着目すると, OSOS2 の Case-1 が最大 で 30 度の差異を示したが，それ以外は 15 度以下の範囲に収まり， 概衫同じ方向を示すことが分かる。残る 2 つの単独地震の主軸方向 は, $\bar{V}_{E}$ の值が小さい場合に三連動地震との差異が大きいが, $\bar{V}_{E}$ の 值が大きい予測波では, 概ね三連動地震と一致する傾向が認められ る。次に ${ }_{p} \bar{S}_{V}$ に着目すると, $\bar{V}_{E}$ 同様, 三連動地震と最大単独地震 は概初同じ方向を示している。ただし，どの方向にも同じような最 大応答值を示寸地震動では, 地震動の合成方向間の最大值のばらつ きにより ${ }_{p} \bar{S}_{V}$ の主軸方向が安定して定まらない現象がみられ, AITK のCase-2 では, 三連動地震と最大単独地震の ${ }_{p} \bar{S}_{V}$ の主軸方向が概ね 直交している。このような地震動では, どの方向にも同じような最 大応答值を示寸ため, 平均 $V_{E}$ の主軸方向での地震動を用いて, 最大 応答值を検討しても問題がないと考えている。以上から, 本論文で は, 主軸方向の設定においても対応関係が明確な $\bar{V}_{E}$ を基準とするこ ととし, 各地点で想定すべき地震動は, これら主軸方向の予測波と して議論を進める。

\section{3. 三連動地震と単独地震のスペクトルの対応関係}

\section{1 スペクトルに対する三連動地震と単独地震の対応式}

北村らは, 複数の地震動が間隔を空けて順に発生した場合につい て, 時刻歴応答解析に基づく検討を行い, Fig.4 に示寸ように, 建物 応答の最大值がそれのみで応答が最大となる単独地震に支配され, 入力エネルギーが各地震動の累積值となることを示している ${ }^{7)} 。$

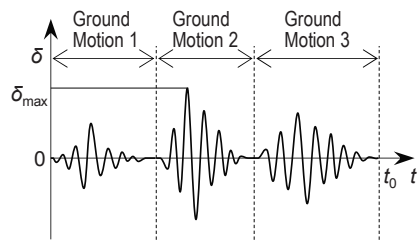

(a) Time history of displacement

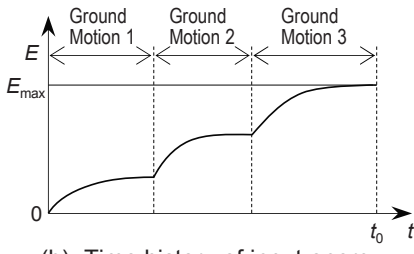

(b) Time history of input energy
この考え方に基づき $n$ 個の地震動の連動を評価しようとすると, 応 答スペクトル ${ }_{p} S_{V}$ と入力エネルギー $E$ は, 式(1), (2a)で表される。 また式(2a)より，速度換算值であるエネルギースペクトル $V_{E}$ $(=\sqrt{2 E / M}, M:$ 構造物の総質量 $)$ は式(2b)で表される。ここで, 添え字の $i$ は単独地震を応答レベルが大きい順に 1 から並べたもの である。

$$
\begin{aligned}
& { }_{p} S_{V}=\operatorname{Max}\left\{{ }_{p} S_{V, i}: i=1,2, \cdots, n\right\} \\
& E=\sum_{i=1}^{n} E_{i}, \quad V_{E}=\sqrt{\sum_{i=1}^{n} V_{E, i}^{2}}
\end{aligned}
$$

これに対し, 単独地震の発生間隔が接近して地震動が相互に干涉 する場合には, 建物応答の最大值が, 最大単独地震時よりも増大寸 ることが予想される。この場合について, 本論文では, 個々の単独 地震に対する応答の最大值の二乗和平方根 (SRSS) として, 応答レ

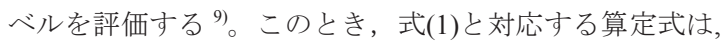

$$
{ }_{p} S_{V}=\sqrt{\sum_{i=1}^{n}{ }_{p} S_{V, i}^{2}}
$$

と表される。さらに, 個々の単独地震による最大值が完全に一致す る場合が予測される最大のケースであり, 応答スペクトルの最大值 の和として, 次式のように表される。

$$
{ }_{p} S_{V}=\sum_{i=1}^{n}{ }_{p} S_{V, i}
$$

これら建物応答の最大值に対し, 入力エネルギーは単独地震の和 として式(2a,b)により評価されるが ${ }^{9)}$ ，ここでは水平 2 成分の入力 エネルギーの和を, その地震による入力エネルギーとして累積值を 安全側に評価することを考える ${ }^{13)}$ 。この考え方は, 過度に安全側の 評価を与えるように思われるが，Fig.3 にも認められるように，比 較的レベルが大きい単独地震では, 主軸と直交する方向の影響が小 さく, 両方向の和と主軸のみを評価した入力エネルギーの差異は概 して小さい。また, 後述する時刻歴応答解析に基づく検証でも, 水 平 2 成分で評価した入力エネルギーが, 建物応答の累積值を過大に 見積もる訳ではなかったため, 本論文では以上の設定を採用し, 式 $(2 \mathrm{a}, \mathrm{b})$ と対応する算定式を，次式で与えることにする。

$$
E=\sum_{i=1}^{n}\left({ }_{N S} E_{i}+{ }_{E W} E_{i}\right), \quad V_{E}=\sqrt{\sum_{i=1}^{n}\left({ }_{N S} V_{E, i}{ }^{2}+{ }_{E W} V_{E, i}{ }^{2}\right)}
$$

\section{2 応答スペクトルにおける三連動地震と単独地震の対応}

前節に示した単独地震と三連動地震の対応関係として, まず擬似 速度応答スペクトルに着目し，式(1),(3),(4)の対応関係を検証する。 Fig. 5 には, 大阪平野, 濃尾平野, 関東平野における擬似速度応答ス ペクトル ${ }_{p} S_{V}(h=5 \%)$ として, 三連動地震の主軸方向による計算結 果と, 単独地震の主軸方向の計算結果より式(1),(3),(4)を介して評価 した応答スペクトルを比較して示してある。同図では, 各平野から 2 地点を代表して OSKH, OSOS, MIYK, AING, TKTK, CBMTの 6 地点を表示してある。また, 同図は「特定の周期帯」以外の周期 帯域を網掛けにして表示し, 5 章で用いる超高層建物モデルの 1 次 固有周期 $T_{1}$ を，参考として示してある。

Fig.5 より, まず最大単独地震のエネルギースペクトルより定めた 「特定の周期帯」が，擬似速度応答スペクトル ${ }_{p} S_{V}$ が卓越している 周期带域と良好に対応していることが確認され, 設定方法が妥当で あると判断される。また, 三連動地震と式(1),(3),(4)より求めた応答 スペクトルを比較すると, 三連動地震による応答は, 式(1)と(4)の中 間に位置し, 式(3)に良好な対応関係を示すことが分かる。一部で, 三連動地震による ${ }_{p} S_{V}$ が, 式(1)による評価より小さい部分もあるが, このような場合は, 而震安全性を検討する三連動地震として適して いないため, 本論文では取り扱わない。

続いて Fig.6 には, 全 12 地点の擬似速度応答スペクトルを「特 定の周期帯」で平均化した結果をまとめてある。同図より，応答ス ペクトルは, 式(1)が概ね三連動地震の下限值を与え, 式(4)がすべて の地点で上限值を与えていることが分かる。破壊開始点の違いで式 (3) と三連動地震の大小関係が異なるものの, 全 12 地点を通して式 (3)は三連動地震と概ね一致している。以上の結果より, 三連動地震 の擬似速度応答スペクトルは, 式(1)を下限值, 式(4)を上限值として, 式(3)による評価で概初応答レベルを想定できると考えられる。

3.3 エネルギースペクトルにおける三連動地震と単独地震の対応 前節に続き, 3.1 節に述べたエネルギースペクトルに対する単独 

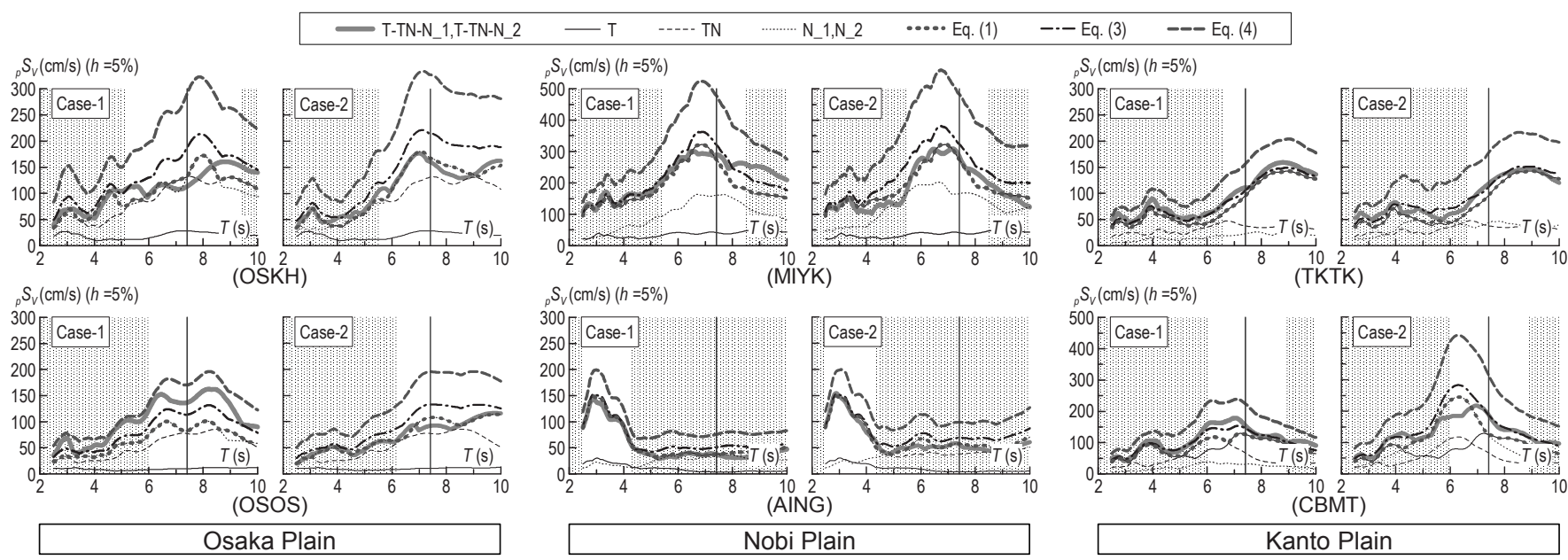

Fig.5 Pseudo-velocity response spectra at each site
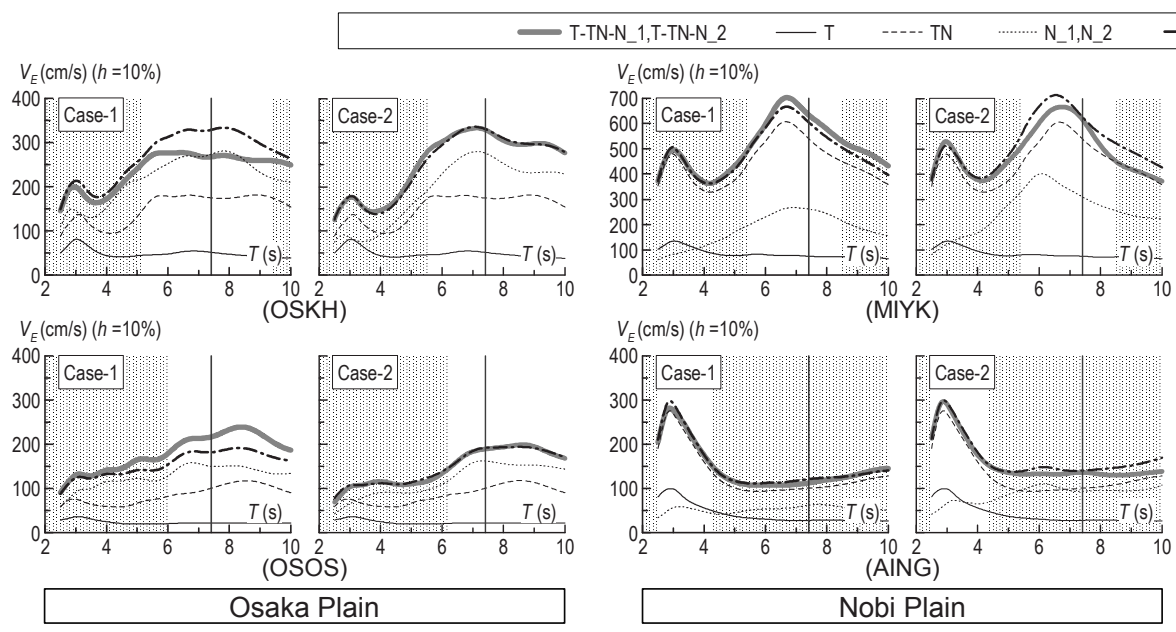

Fig.7 Energy spectra at each site

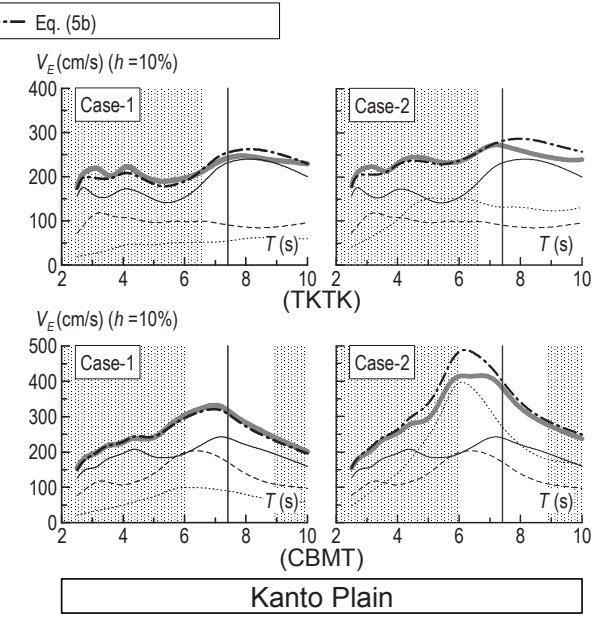

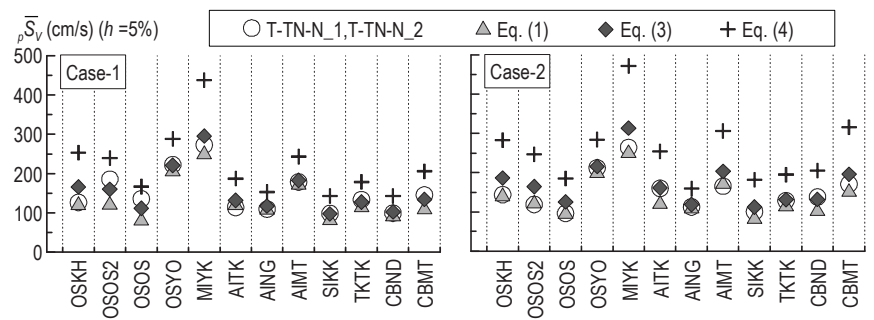

Fig.6 Comparison with estimates in average pseudo-velocity response spectra $(h=5 \%)$

地震と三連動地震の対応関係として, 式(5b)の妥当性を検証する。

Fig.7 には, 前節 Fig.5 と同様に, 大阪平野, 濃尾平野, 関東平野の 各地点おける三連動地震の水平 2 成分より求めたエネルギースペク トル $(h=10 \%)$ と, 単独地震の計算結果から式 $(5 \mathrm{~b})$ により連動地震 を評価した結果を比較して示してある。

Fig.7で「特定の周期帯」で三連動地震と単独地震のエネルギース ペクトルを比較すると, OSKH(Case-1)の一部の周期帯域を除けば, 三連動地震のエネルギースペクトルは, 単独地震より大きいことが 分かる。これに対して, 式(5b)より評価したエネルギースペクトル は, OSOS(Case-1) や MIYK(Case-1) で例外的に三連動地震を下回る が, それ以外の検討地点や地震発生ケースでは, 三連動地震による 計算結果を上回るか良好な対応関係を示している。

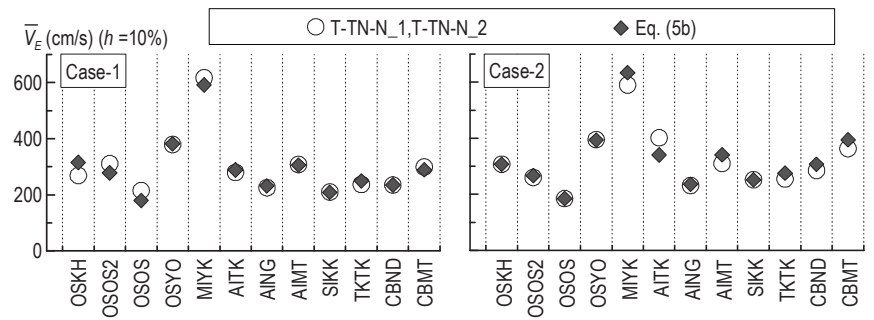

Fig. 8 Comparison with estimates in average energy spectra $(h=10 \%)$

Fig.8 には, Fig.6 と同様に 12 地点のエネルギースペクトルを「特 定の周期帯」で平均化した結果が示してある。同図より，三連動地 震の平均エネルギースペクトルは, 計算地点によらず式(5b) と良好 に対応している。以上から，三連動地震の入力エネルギーは，それ を構成する単独地震の総和として式(5a)により評価することができ ると考えられる。

\section{4. 多質点弾塑性系における三連動地震の応答評価法}

\section{1 単独地震による三連動地震の応答評価の考え方}

任意の構造物の単独地震に対する応答解析の結果から, 三連動地 震による最大応答值と累積值を想定することを目的に, 前章で述べ た擬似速度応答スペクトルの SRSS として評価する考え方を応答の 
最大值に, エネルギースペクトルにおける単独地震の総和として評 価する考え方を累積値に適用寸ることを考える。建物応答の最大値 と累積值の評価指標として, 層間変形角 $R$, 部材の塑性率 $\mu_{m}$ と, 層 と部材の累積塑性変形倍率 $\eta, \eta_{m}$ を用いる。第 $i$ 層の累積塑性変形倍 率 $\eta_{i}$ は, 主架構の塑性歪エネルギー $W_{p i}$ と, 等価降伏変位 $\delta_{e q}$, 等価 降伏耐力 $Q_{e q i}$ を用いて下式より求められる。

$$
\eta_{i}=W_{p i} /\left(\delta_{e q i} \cdot Q_{e q i}\right)
$$

$\delta_{e q i}$ と $Q_{e q i}$ は, 静的荷重増分解析より求められる各層の層せん断力 一層間変形角関係を基に, 層間変形角 $R_{i}=1 / 50 \mathrm{rad}$ までの履歴面積が 等しくなる完全弾塑性型の復元力特性を求めた際の等価降伏変位と 等価降伏耐力である。概要を Fig.9 に示す。

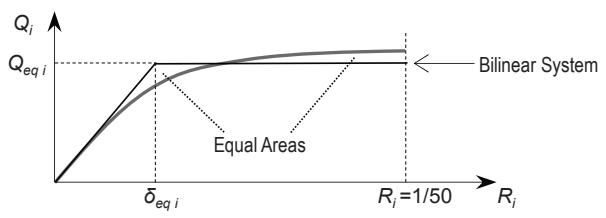

Fig.9 Relationship between story shear force and story drift angle

既往研究では, 単独地震が十分な時間間隔をおいて連続的に発生 寸る場合, 個々の単独地震による応答解析の結果から三連動地震に よる応答を想定できるが, 弾塑性応答解析では, それまで経験した 地震動による残留変形を考慮する必要があることを報告している7)。 一方, 単独地震が相互に干涉する場合, 三連動地震の最大応答值が 個々の単独地震の最大応答值を上回ることが予想されるため, 本論 文では式(3)を適用し，応答スペクトルの評価にSRSS を用いた。

この考え方を踏襲すると, 層間変形角 $R$ や部材の塑性率 $\mu_{m}$ の評価 には, 単独地震による応答解析の結果の SRSS を用いることが考え られるが, 弾塑性解析では影響が小さい単独地震の多くが弾性応答 に留まるため, 三連動地震による応答が適切に評価できない。以上 を踏まえ, 本論文では他の単独地震による影響をスペクトル上で考 慮する方法を提案する。具体的には, 前章で述べた通り, 三連動地 震のレベルを単独地震の SRSS として評価し, それらの差異を増幅 係数として考慮した上で応答解析を行う ${ }^{10)}$ 。

応答解析に用いる入力波は, 各単独地震の主軸方向の地震動に, 次のように定める増幅係数 $a_{k}$ を乗じたものとする。Fig.10 に示すよ うに, 増幅係数 $a_{k}$ は $k$ 番目（三連動地震の場合, $k=1 \sim 3$ ) の単独 地震の平均速度応答スペクトル $\bar{S}_{V, k}$ と, 式(3)より評価した三連動 地震を想定したレベルの比率で, 次式で表される。

$$
a_{k}=\sqrt{\sum_{i=1}^{n}{ }_{p} S_{V, i}^{2}} /{ }_{p} \bar{S}_{V, k}
$$



Fig.10 Method of increasing an earthquake to the level of the multi-segment earthquake

ここで一度記号を整理する。まず, 加速度振幅を $a_{k}$ 倍した単独地
震の擬似速度応答スペクトルを ${ }_{a k, p} S_{V}$, 入力エネルギーを ${ }_{a k} E$, エネ ルギースペクトルを ${ }_{a k} V_{E}$ と表す。また, 応答解析により得られる建 物応答の第 $i$ 層の層間変形角を ${ }_{a k} R_{i}$, 層の塑性歪エネルギーを ${ }_{a k} W_{p i}$ と寸る。ここで, 左下添え字の $a k$ は, $k$ 番目の単独地震の加速度波 形を $a_{k}$ 倍して得た応答であることを意味する。 ${ }_{a k, p} S_{V}$ と ${ }_{a k} V_{E}$ はもと の単独地震の ${ }_{k, p} S_{V},{ }_{k} V_{E}$ を $a_{k}$ 倍, ${ }_{a k} E$ は ${ }_{k} E$ を $a_{k}{ }^{2}$ 倍した值である。

三連動地震による建物応答の最大値は, 式(7)で求まる増幅係数 $a_{1}$

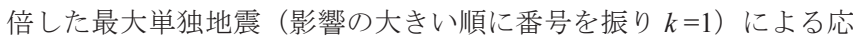
答解析結果を用いる。必要に応じ, 2 番目に影響の大きい単独地震 による応答解析の結果も考慮するが，この点は次節で言及する。 $a_{1}$ 倍した最大単独地震による応答解析の結果から, 三連動地震による 累積值を推定する上では，エネルギーの釣合に基づく応答予測式を

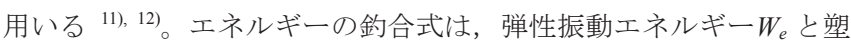
性歪エネルギー $W_{p}$, 減衰で消費するエネルギー $W_{h}$ の和が入力エネル ギーEと釣り合うことから，次式で表される。

$$
W_{e}+W_{p}+W_{h}=E
$$

地震終了時は, 弾性振動エネルギー $W_{e}=0$ となり,

$$
W_{p}+W_{h}=E
$$

と書き換えられる。入力エネルギー $E$ の速度換算值を $V_{E}(=\sqrt{2 E / M}$, $M$ : 総質量） と表し，入力エネルギー $E$ から減衰により消費するエ ネルギー $W_{h}$ を除いた損傷に寄与寸るエネルギーを $E_{D}$ と呼び，その 速度換算值を $V_{D}\left(=\sqrt{2 E_{D} / M}\right)$ と表記する。すなわち, 地震終了 時には, $W_{p}$ と $E_{D}$ が等しくなる。 $a_{1}$ 倍した最大単独地震の応答解析 から求めた第 $i$ 層の塑性歪エネルギー ${ }_{a 1} W_{p i}$ を用いて, 損傷分散係数 ${ }_{a 1} \gamma_{i}$ を下式により求める。

$$
\frac{1}{{ }_{a 1} \gamma_{i}}=\frac{{ }_{a 1} W_{p i}}{{ }_{a 1} W_{p}}=\frac{{ }_{a 1} W_{p i}}{\sum_{j=1}^{N}{ }_{a 1} W_{p j}}
$$

3.3 節の検討から, 三連動地震による総入力エネルギーを, 単独 地震の総入力エネルギーの総和とする。単独地震の主軸方向の入力 エネルギーの総和から求めた三連動地震のエネルギースペクトル (式(2b)）の平均值を ${ }_{T, M} \bar{V}_{E}$, 単独地震の水平 2 成分の総入力エネ ルギーの総和から求めたエネルギースペクトル（式(5b)）の平均值 を ${ }_{T, 0} \bar{V}_{E}$ で表す。 $a_{1}$ 倍した最大単独地震のエネルギースペクトルの平 均值 ${ }_{a 1} \bar{V}_{E}$ と塑性歪エネルギー ${ }_{a 1} W_{p}$ を用いて, 三連動地震による塑性 歪エネルギー $W_{p}$ は, 主軸方向と水平 2 成分の和によるエネルギース ペクトルの平均值 ${ }_{T, M} \bar{V}_{E}$ と ${ }_{T, 0} \bar{V}_{E}$ から, それぞれ下式で表される。

$$
\begin{aligned}
& W_{p}=\left(\frac{T, M}{{ }_{a 1} \bar{V}_{E}}\right)^{2} \cdot{ }_{a 1} W_{p} \\
& W_{p}=\left(\frac{{ }_{T, 0} \bar{V}_{E}}{{ }_{a 1} \bar{V}_{E}}\right)^{2} \cdot{ }_{a 1} W_{p}
\end{aligned}
$$

架構全体の塑性歪エネルギー $W_{p}$ から, 各層の塑性歪エネルギー $W_{p i}$ は, 損傷分散係数 ${ }_{a 1} \gamma_{i}$ を用いて次式で求められる。

$$
W_{p i}=\frac{W_{p}}{{ }_{a 1} \gamma_{i}}
$$

累積塑性変形倍率 $\eta_{i}$ は, 式(13)で求めた $W_{p i}$ を式(6)に代入するこ 
とで求められる。式(11)は単独地震の主軸方向の入力エネルギーの 総和, 式(12) は水平 2 成分の総入力エネルギーの総和を意味し, 式(13)を用いることで三連動地震による 1 方向入力時の各層の累積 值を推定している。したがって, 三連動地震の累積值は, 平均的な 值を求める場合に式(11)を, 安全側の大きめの值を想定する場合に 式(12)を用いて評価することになる。

\section{2 複数の地震による影響を考慮する場合}

最大単独地震による応答が, 他の単独地震の応答より明らかに大 きい場合は, 最大単独地震による応答解析の結果のみを利用すれば よい。しかし，この方法のみでは応答を適切に表現できない場合が あるため, 本節では, 複数の単独地震による応答を考慮する場合に ついて, 建物応答の最大值と累積值の算定方法をまとめる。

$k$ 番目の単独地震の入力エネルギーが考慮する単独地震の入力エ ネルギーの総和に占める割合を $e_{k}$ とすると, エネルギースペクトル の平均值 ${ }_{k} \bar{V}_{E}$ を用いて次式で表される。同式で, $n$ は考慮する単独 地震の個数を意味する。

$$
e_{k}=\frac{{ }_{k} \bar{V}_{E}^{2}}{\sum_{i=1}^{n} \bar{V}_{E}^{2}}
$$

入力エネルギーの割合 $e_{k}$ を用いて, 複数の単独地震の $a_{k}$ 倍された 地震動による層間変形角 ${ }_{a k} R_{i}$ と部材の塑性率 ${ }_{a k} \mu_{m i}$ から, 三連動地震 の層間変形角 $R_{i}$ と部材の塑性率 $\mu_{m i}$ をそれぞれ下式で推定する。

$$
R_{i}=\sum_{k=1}^{n}\left(e_{k} \cdot{ }_{a k} R_{i}\right), \quad \mu_{m i}=\sum_{k=1}^{n}\left(e_{k} \cdot{ }_{a k} \mu_{m i}\right)
$$

三連動地震の損傷分散係数 $\gamma_{i}$ は, 式(10)を $k$ 番目の単独地震の式 に変換した第 $i$ 層の損傷分散係数 ${ }_{a k} \gamma_{i}$ を用いて,

$$
\frac{1}{\gamma_{i}}=\sum_{k=1}^{n}\left(e_{k} \cdot \frac{1}{{ }_{a k} \gamma_{i}}\right)=\sum_{k=1}^{n}\left(e_{k} \cdot \frac{{ }_{a k} W_{p i}}{{ }_{a k} W_{p}}\right)
$$

とする。これにより, 三連動地震の累積值は, 式(13)の ${ }_{a 1} \gamma_{i}$ を式(16) の $\gamma_{i}$ に置き換えて, 式(6)より推定する。

\section{5. 建物モデルを用いた単独地震の応答による三連動地震の 応答評価}

\section{1 検討対象建物モデルの概要}

検討には, 地上 50 階, 高さ約 $200 \mathrm{~m}$, 純ラーメン架構の超高層鋼 構造建物を用いる。Fig.11,12 に対象建物の軸組図と基準階伏図, Table4 に主要部材断面を示す。静的荷重増分解析, 時刻歷応答解析 ともに, 各部材をモデル化した立体骨組モデルを使用し, 各階は剛 床仮定としてある。以降では, これを解析モデルと呼び, 長辺方向 （X 方向）を対象に議論を進める。Fig.13には, 静的荷重増分解析 より得られた解析モデルの荷重変形関係が示してある。同図は, 各 層のいずれかの部材が降伏曲げモーメントに達したときを○印, 各 層のいずれかの部材が全塑性モーメントに達したときをの印で表示 してある。いずれかの部材が最初に全塑性モーメントに達したとき のベースシア係数は 0.048 で, いずれかの層の層間変形角 $R$ が $1 / 50$ に達したときを終局耐力時とすると, このときのベースシア係数は 0.057 である。建物全重量は $806,000 \mathrm{kN}$, 架構の 1 次固有周期 $T_{1}$ は $7.41 \mathrm{~s}$ である。時刻歴応答解析では, 架構の 1 次固有周期 $T_{1}$ に対し, $h=0.02$ の初期剛性比例型の構造減衰を用いた。

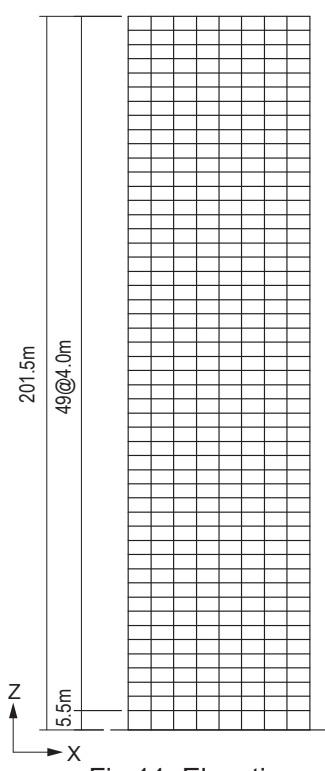

Fig.11 Elevation

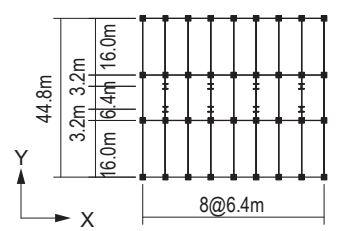

Fig.12 Plan

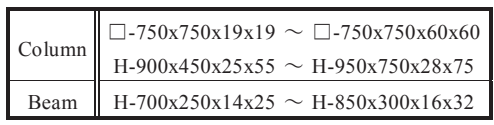

$Q(\mathrm{kN})$

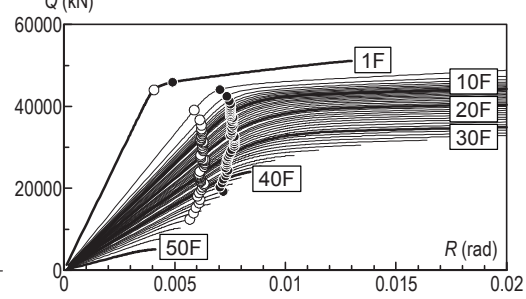

Fig.13 Load-deformation relation of the model
Table4 Members

Table5 The value of $a_{k}$

\begin{tabular}{|c|c|c|c|c|c|c|}
\hline \multirow{3}{*}{ Site } & \multicolumn{6}{|c|}{ Earthquake } \\
\cline { 2 - 7 } & \multicolumn{3}{|c|}{ Case-1 } & \multicolumn{3}{|c|}{ Case-2 } \\
\cline { 2 - 7 } & T & TN & N_1 & T & TN & N_2 \\
\hline \hline OSKH & 7.73 & 1.42 & 1.43 & 8.21 & 1.52 & 1.35 \\
\hline TKTK & 1.08 & 3.11 & 5.52 & 1.12 & 3.22 & 3.22 \\
\hline
\end{tabular}

Table6 Comparison between elastic response analysis and

\begin{tabular}{|c|c|c|c|c|c|c|c|c|c|c|}
\hline \multirow{4}{*}{ Earthquake } & \multicolumn{5}{|c|}{ Case-1 } & \multicolumn{5}{|c|}{ Case-2 } \\
\hline & \multirow{2}{*}{\multicolumn{2}{|c|}{$\begin{array}{c}\text { Average energy } \\
\text { spectrum } \bar{V}_{E} \\
(\mathrm{~cm} / \mathrm{s})\end{array}$}} & \multicolumn{3}{|c|}{$\begin{array}{c}\text { Nonlinear Response } \\
\text { Analysis of the Model }\end{array}$} & \multirow{2}{*}{\multicolumn{2}{|c|}{$\begin{array}{c}\text { Average energy } \\
\text { spectrum } \bar{V}_{E} \\
(\mathrm{~cm} / \mathrm{s})\end{array}$}} & \multicolumn{3}{|c|}{$\begin{array}{c}\text { Nonlinear Response } \\
\text { Analysis of the Model }\end{array}$} \\
\hline & & & \multirow{2}{*}{\begin{tabular}{|c|}
$\begin{array}{c}V_{D} \\
(\mathrm{~cm} / \mathrm{s})\end{array}$ \\
$\begin{array}{c}\text { Principal } \\
\text { Axis }\end{array}$ \\
\end{tabular}} & \multirow{2}{*}{\begin{tabular}{|c|}
$\begin{array}{c}V_{E} \\
(\mathrm{~cm} / \mathrm{s})\end{array}$ \\
$\begin{array}{c}\text { Principal } \\
\text { Axis }\end{array}$ \\
\end{tabular}} & \multirow{2}{*}{\begin{tabular}{|c|}
$E_{D} / E$ \\
$\begin{array}{c}\text { Principal } \\
\text { Axis }\end{array}$ \\
\end{tabular}} & & & \multirow{2}{*}{\begin{tabular}{|c|}
$\begin{array}{c}V_{D} \\
(\mathrm{~cm} / \mathrm{s})\end{array}$ \\
$\begin{array}{c}\text { Principal } \\
\text { Axis }\end{array}$ \\
\end{tabular}} & \multirow{2}{*}{\begin{tabular}{|c|}
$\begin{array}{c}V_{E} \\
(\mathrm{~cm} / \mathrm{s})\end{array}$ \\
$\begin{array}{c}\text { Principal } \\
\text { Axis }\end{array}$ \\
\end{tabular}} & \multirow{2}{*}{\begin{tabular}{|c|}
$E_{D} / E$ \\
$\begin{array}{c}\text { Principa } \\
\text { Axis }\end{array}$ \\
\end{tabular}} \\
\hline & $\begin{array}{l}\text { Principal } \\
\text { Axis }\end{array}$ & \begin{tabular}{|c|} 
Two \\
$\begin{array}{c}\text { Directions } \\
\text { Sum }\end{array}$ \\
\end{tabular} & & & & $\begin{array}{l}\text { Principal } \\
\text { Axis }\end{array}$ & \begin{tabular}{|c} 
Two \\
$\begin{array}{c}\text { Directions } \\
\text { Sum }\end{array}$ \\
\end{tabular} & & & \\
\hline $\mathrm{T}$ & 39.6 & 47.8 & 0.0 & 44.3 & 0.00 & 38.7 & 46.7 & 0.0 & 44.3 & 0.00 \\
\hline $\mathrm{TN}$ & 157.3 & 176.4 & 114.9 & 144.3 & 0.63 & 160.0 & 176.0 & 114.9 & 144.3 & 0.63 \\
\hline $\mathrm{N} \_1, \mathrm{~N} \_2$ & 205.3 & 256.3 & 163.7 & 216.5 & 0.57 & 211.3 & 246.1 & 165.8 & 205.5 & 0.65 \\
\hline $\mathrm{T}^{\prime}$ & 306.4 & - & 209.1 & 276.5 & 0.57 & 317.9 & - & 221.0 & 289.8 & 0.58 \\
\hline TN' & 223.4 & - & 159.8 & 192.3 & 0.69 & 242.8 & - & 169.0 & 202.8 & 0.69 \\
\hline N_1', N_2' & 294.5 & - & 234.9 & 285.8 & 0.68 & 285.0 & - & 211.2 & 249.2 & 0.72 \\
\hline Eq.(2b) & 262.1 & - & - & & & 268.3 & 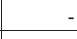 & - & & \\
\hline Eq. $(5 b)$ & & 315.0 & & & & & 306.5 & & & \\
\hline $\begin{array}{l}\text { T-TN-N_1 } \\
\text { T-TN-N_2 }\end{array}$ & 209.6 & 268.5 & 117.0 & 187.8 & 0.39 & 266.2 & 307.0 & 202.6 & 250.3 & 0.66 \\
\hline
\end{tabular}
nonlinear response analysis in input energy

(a) $\mathrm{OSKH}$

\begin{tabular}{|c|c|c|c|c|c|c|c|c|c|c|}
\hline \multirow{4}{*}{ Earthquake } & \multicolumn{5}{|c|}{ Case-1 } & \multicolumn{5}{|c|}{ Case-2 } \\
\hline & \multirow{2}{*}{\multicolumn{2}{|c|}{$\begin{array}{l}\text { Average energy } \\
\text { spectrum } \bar{V}_{E} \\
(\mathrm{~cm} / \mathrm{s})\end{array}$}} & \multicolumn{3}{|c|}{$\begin{array}{c}\text { Nonlinear Response } \\
\text { Analysis of the Model }\end{array}$} & \multirow{2}{*}{\multicolumn{2}{|c|}{$\begin{array}{c}\text { Average energy } \\
\text { spectrum } \bar{V}_{E} \\
(\mathrm{~cm} / \mathrm{s})\end{array}$}} & \multicolumn{3}{|c|}{$\begin{array}{l}\text { Nonlinear Response } \\
\text { Analysis of the Model }\end{array}$} \\
\hline & & & \multirow{2}{*}{\begin{tabular}{|c|}
$\begin{array}{c}V_{D} \\
(\mathrm{~cm} / \mathrm{s})\end{array}$ \\
$\begin{array}{c}\text { Principal } \\
\text { Axis }\end{array}$ \\
\end{tabular}} & \multirow{2}{*}{\begin{tabular}{|c|}
$\begin{array}{c}V_{E} \\
(\mathrm{~cm} / \mathrm{s})\end{array}$ \\
$\begin{array}{c}\text { Principal } \\
\text { Axis }\end{array}$ \\
\end{tabular}} & \multirow{2}{*}{\begin{tabular}{|c|}
$E_{D} / E$ \\
$\begin{array}{c}\text { Principal } \\
\text { Axis }\end{array}$ \\
\end{tabular}} & & & \multirow{2}{*}{\begin{tabular}{|c|}
$\begin{array}{c}V_{D} \\
(\mathrm{~cm} / \mathrm{s})\end{array}$ \\
$\begin{array}{c}\text { Principal } \\
\text { Axis }\end{array}$ \\
\end{tabular}} & \multirow{2}{*}{\begin{tabular}{|c|}
$\begin{array}{c}V_{E} \\
(\mathrm{~cm} / \mathrm{s})\end{array}$ \\
$\begin{array}{c}\text { Principal } \\
\text { Axis }\end{array}$ \\
\end{tabular}} & \multirow{2}{*}{\begin{tabular}{|c|}
$E_{D} / E$ \\
$\begin{array}{c}\text { Principa } \\
\text { Axis }\end{array}$ \\
\end{tabular}} \\
\hline & $\begin{array}{c}\text { Principal } \\
\text { Axis }\end{array}$ & \begin{tabular}{|c|} 
Two \\
Directions \\
Sum \\
\end{tabular} & & & & \begin{tabular}{c|} 
Principal \\
Axis
\end{tabular} & \begin{tabular}{|c|} 
Two \\
$\begin{array}{c}\text { Directions } \\
\text { Sum }\end{array}$ \\
\end{tabular} & & & \\
\hline $\mathrm{T}$ & 183.8 & 225.1 & 89.7 & 158.5 & 0.32 & 183.8 & 225.1 & 89.7 & 158.5 & 0.32 \\
\hline $\mathrm{TN}$ & 67.5 & 89.7 & 0.0 & 66.8 & 0.00 & 67.5 & 89.7 & 0.0 & 66.8 & 0.00 \\
\hline $\mathrm{N} \_1, \mathrm{~N} \_2$ & 50.4 & 58.7 & 0.0 & 38.1 & 0.00 & 97.9 & 129.5 & 1.4 & 83.3 & 0.00 \\
\hline $\mathrm{T}$, & 198.5 & - & 101.6 & 169.9 & 0.36 & 205.5 & & 107.7 & 175.8 & 0.38 \\
\hline TN' & 209.7 & - & 105.6 & 198.1 & 0.28 & 217.1 & & 111.4 & 203.9 & 0.30 \\
\hline N_1', N_2' & 278.4 & - & 134.2 & 216.0 & 0.39 & 315.4 & & 223.3 & 291.0 & 0.59 \\
\hline Eq.(2b) & 202.5 & 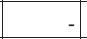 & - & - & - & 219.3 & & & -1 & \\
\hline Eq.(5b) & & 249.5 & - & - & & - & 275.0 & & - & \\
\hline $\begin{array}{l}\text { T-TN-N_1 } \\
\text { T-TN-N_2 }\end{array}$ & 196.6 & 237.1 & 120.8 & 178.5 & 0.46 & 198.2 & 254.2 & 123.7 & 187.5 & 0.44 \\
\hline
\end{tabular}

(b) TKTK 


\section{2 単独地震による三連動地震の最大応答値の評価}

4 章で述べた最大単独地震による応答解析の結果から, 三連動地 震による解析モデル各層の応答の最大值を想定する方法を検証する。 以降では, 解析モデルの 1 次固有周期 $T_{1}$ が検討地点の「特定の周期 帯」に含まれ, 超高層建物が比較的多く立ち並ぶ OSKH と TKTKに おける応答を代表として示す。Table5に, 式(7)より算出した OSKH と TKTKにおける $a_{k}$ の值を示す。同表より, OSKHでは, 最大単独 地震とした南海地震に加えて東南海地震が $a_{k}=1.0$ に近い值を示し, 増幅率が小さいことが分かる。Table6 には, 検討地点の平均エネル ギースペクトル $\bar{V}_{E}$ と解析モデルへの入力エネルギーをまとめて示 している。ここで, 表中の「’」は, 地震動の入力加速度波形を $a_{k}$ 倍したことを意味する。同表より,「特定の周期帯」における $\bar{V}_{E} に$ 着目すると, それぞれの地点の最大単独地震以外に, OSKH(Case-1, 2)で東南海地震, TKTK(Case-2)で南海地震の影響が他の地震よりも 大きく, $100 \mathrm{~cm} / \mathrm{s}$ を上回っていることが分かる。また，同表の解析 モデルの損傷に寄与するエネルギー入力 $E_{D}\left(=W_{p}\right)$ の速度換算值 $V_{D}$ に着目すると, これらの地震で 0 より大きく, 架構が塑性化してい ることが分かる。このため, 以降の検討では, 最大単独地震である OSKH の南海地震と TKTK の東海地震を $k=1$ とし, OSKH(Case-1, 2) と TKTK(Case-2)では，それぞれ東南海地震と南海地震を $k=2$ とし て, 4.2 節で述べた複数の地震による影響を考慮する方法を用いる。

Fig.14 には, 各地震で想定する入力波を, 式(7)に従い $a_{k}$ 倍した応 答解析の結果として層間変形角 ${ }_{a k} R$ と, 式(15a)より算出した值, 三 連動地震の予測波による層間変形角を示している。Fig.14より, OSKH(Case-1)を除き， $a_{1}$ 倍された単独地震より得た ${ }_{a 1} R$ は三連動地 震と良好な対応関係を示していることが分かる。また， OSKH(Case-2) と TKTK(Case-2) においては, 他の地震動を考慮し た式(15a)により ${ }_{a 1} R$ よりも三連動地震との差異を小さくしている ことが確認できる。

続いて $a_{k}$ 倍された単独地震による各層の部材の最大塑性率 ${ }_{a k} \mu_{m}$ と, 式(15b)より評価した結果, および三連動地震による部材の塑性率を 比較する。Fig.15 に部材の塑性率の高さ方向の分布を示す。Fig.15 より, 先と同様, $a_{1}$ 倍された単独地震より得た ${ }_{a 1} \mu_{m}$ と式(15b)による 值が三連動地震と良好な対応を示し, 層の最大值に加えて部材の最 大值においても, 単独地震を $a_{k}$ 倍して応答解析する考え方が有効で あると認められる。

\section{3 累積値に対する三連動地震と単独地震の対応}

5.2 節と同様に, OSKH では南海地震を $k=1$, 東南海地震を $k=2$ とし, TKTK では東海地震を $k=1$, TKTK の Case-2 はこれに南海地 震を $k=2$ として加え, 累積值の検討を行う。Fig.16,17 に, 層と部 材の損傷分散係数をそれぞれ示す。図中では， $a_{k}$ 倍された単独地震 による応答解析で得た損傷分散係数の逆数 $1 /_{a k} \gamma$ と, 式(16)の值, 三 連動地震の予測波により得た損傷分散係数の逆数 $1 / \gamma$ を示している。 Fig.16,17より， $a_{1}$ 倍された単独地震による応答解析から得られた $1 / a_{a 1} \gamma$ と式(16)による $1 / \gamma$ は, 三連動地震により得られた $1 / \gamma$ と良好 な対応関係を示し， $a_{k}$ 倍された地震動を利用することで三連動地震 の $1 / \gamma$ を概ね捉えられていることが分かる。Fig.17(a)より，OSKHの Case-1 で, 20 層を中心に $1 / a_{a 1} \gamma$ や式(16)の $1 / \gamma$ は三連動地震と差異が あるものの, Table6(a)より, Case-1 では三連動地震の $E_{D} / E$ が比較的 小さい。このような傾向は, OSKH や TKTK 以外の検討地点でも現

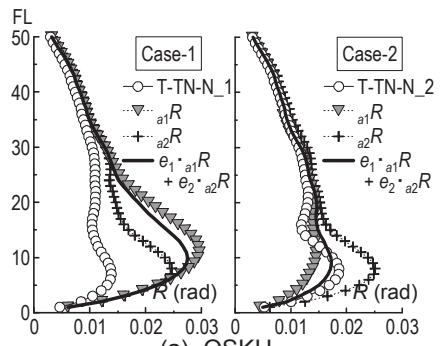

(a) OSKH

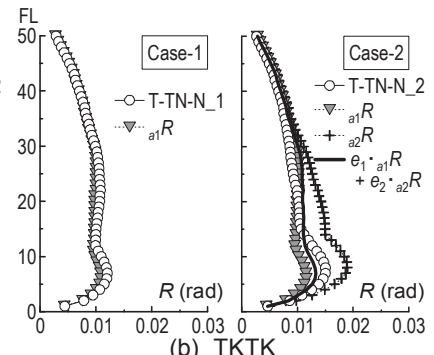

(b) TKTK
Fig.14 Story drift angle

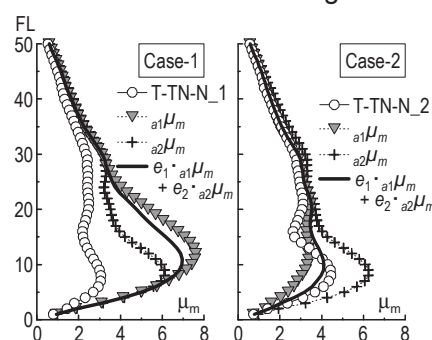

(a) $\mathrm{OSKH}$

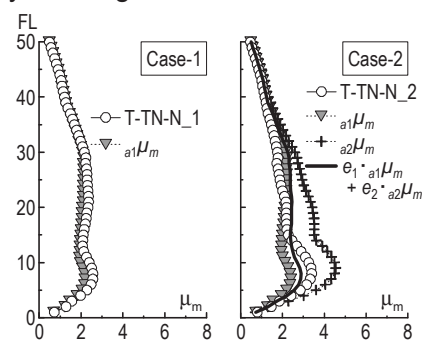

(b) TKTK
Fig.15 Ductility factor of member
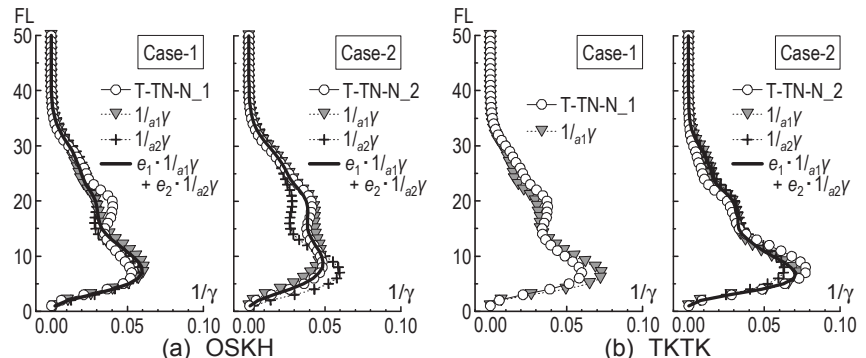

Fig.16 Damage distribution of story



(a) OSKH

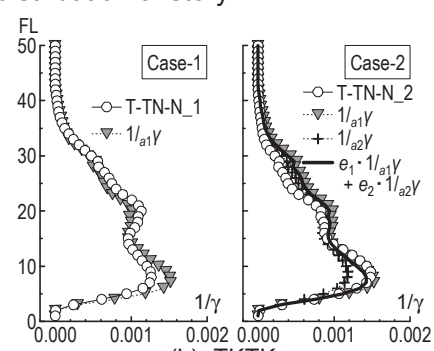

(b) TKTK

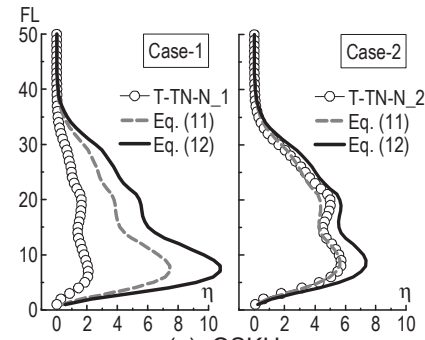

(a) $\mathrm{OSKH}$

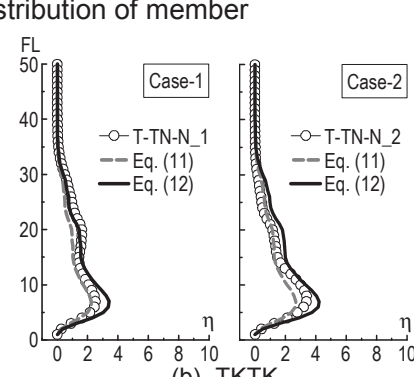

(b) TKTK
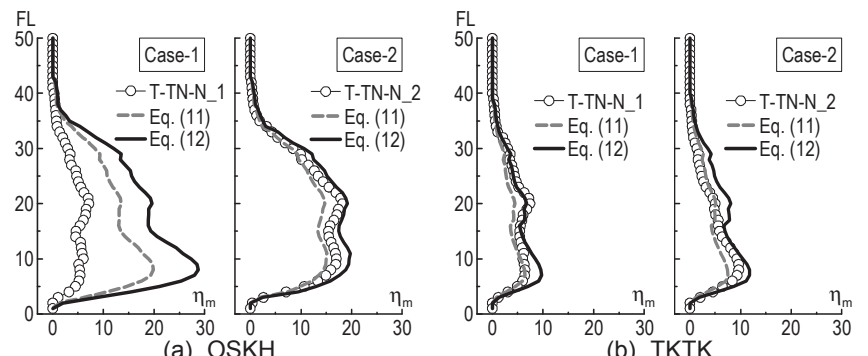

Fig.19 Cumulative plastic deformation of member 
われ, 塑性化の程度が小さい三連動地震の $1 / \gamma$ は, $a_{1}$ 倍された単独 地震による $1 /{ }_{a 1} \gamma$ や式(16)による $1 / \gamma$ と, 差異を生じる傾向を確認し た。以上を踏まえ, 三連動地震の累積值を想定する上では, $1 /{ }_{a 1} \gamma$ または式(16)を利用してエネルギー配分を規定することとする。

Fig.18,19に, 式(11)と式(12)の両者で $W_{p}$ を算出し, 式(6),(13)より 得られた, 層と部材の累積塑性変形倍率を示す。Fig.18,19より, 式 (11)は概ね三連動地震の下限值を与え, 式(12)は三連動地震を包絡す る分布を示しており, OSKH(Case-1)を除き, 三連動地震が最大とな る層では, 式(11)と式(12)が三連動地震の累積值を 5 26\%の差異で挟 みこむ結果となった。したがって, 三連動地震による超高層建物の 層と部材の累積值は, 主軸方向の単独地震の入力エネルギーの総和 と, 水平 2 成分の総入力エネルギーの総和を上下限として入力エネ ルギー量を決定し，1/ ${ }_{a 1} \gamma$ または式(16)に基づいてエネルギー配分を 定めることで，ばらつき幅を持って推定できると考えられる。

5.2 節の Fig.14,15 の最大応答值と 5.3 節の Fig.18,19 の累積值の評 価は, OSKH(Case-1)を除いて検討した。ここで, OSKH(Case-1)の三 連動地震 T-TN-N_1 による応答を評価する。Fig.14,15より, 最大応 答值である層間変形角や部材の塑性率が， $a_{1}$ 倍， $a_{2}$ 倍された最大単 独地震である南海地震 N_1 2 番目に大きい単独地震である東南海 地震 TN による応答值を下回り, 式(15a,b)から求まる推定值よりも 小さくなっている。Fig.18,19 に示すそれぞれ層と部材の累積塑性変 形倍率は, OSKH(Case-1)の T-TN-N_1の応答が式(11),(12)から求まる 推定值よりも小さい。これらは, Fig.5,7より, OSKH(Case-1)の三連 動地震の予測波の $S_{P}$ と $V_{E}$ が, 解析モデルの 1 次固有周期 $T_{1}$ 付近で, OSKH(Case-1)の T-TN-N_1 の最大単独地震 N_1 を下回っていること からも予想できる。はじめにで述べたように，3 つの単独地震から 発生する地震動を重衫合わせて作られた三連動地震は, 個々の地震 の震源モデルや破壊開始点が共通でも, 発生する順序や破壞開始時 刻の差異によって様々な地震動が想定される。したがって,

OSKH(Case-1)の T-TN-N_1のような三連動地震の予測波は, 超高層 建物の応答を評価して耐震安全性を検証するための地震動としては 適切でないと考えられる。式(3)や式(5a,b)を参考にして, 適切な三 連動地震の予測波を選び直す必要があると思われる。

\section{6. おわりに}

震源モデルに基づき計算された南海トラフの三連動地震とそれを 構成する 3 つの単独地震を対象に, 単独地震に対する応答解析の結 果を用いて, 三連動地震による超高層建物の応答の最大值と累積值 を想定する方法を提案した。

応答スペクトルにおける対応関係の検討では, 単独地震の擬似速 度応答スペクトルの二乗和平方根 (SRSS) により三連動地震の応答 レベルを概ね評価できることを確認した。エネルギースペクトルに おける対応関係の検討では, 単独地震の入力エネルギーの総和から 求めたエネルギースペクトルが三連動地震と良好な対応を示した。

続いて, 1 質点弾性減衰系の考え方を多質点弾塑性系に拡張し, 単独地震の応答から三連動地震の最大応答值と累積値を想定する応 答評価法を提案した。提案した評価法を検証するため, 超高層鋼構 造建物を模擬した立体骨組モデルを用いて弾塑性応答解析を行い, 三連動地震の予測波による結果と比較を行った。これにより, 応答 スペクトルにおける対応関係を基に最大単独地震の波形を増幅させ
て応答解析した結果は, 三連動地震の層間変形角と部材の塑性率を 捉えることを確認した。また，エネルギーの釣合に基づく応答予測 式を用いることで，単独地震の入力エネルギーの総和により推定し た入力エネルギーと, 最大単独地震の応答解析から求めた損傷分散 係数から, 層と部材の累積塑性変形倍率を導き, 三連動地震と良好 な対応を示すことを確認した。

本論文は破壊開始点 2 ケース, 検討地点 12 地点の限られた予測波 による検討であるが，単独地震の応答解析の結果を用いて，三連動 地震による超高層建物の最大応答值と累積値を想定する応答評価法 に関する一つの考え方を示せたと考えている。本論文が三連動地震 による建物応答を評価する一助となれば幸いである。

\section{謝辞}

本研究は，大成建設株式会社と東京理科大学北村研究室による地 震動応答研究会の成果の一部をまとめたものです。本論文は, 地震 動応答研究会のメンバーであった須賀貴之氏 (2013 年 3 月修士課程 修了）と佐藤克哉氏（2014 年 3 月修士課程修了）の修士論文の成果 をもとに発展させたものが含まれています。一部の図作成には GMT を使用させていただきました。ここに記して感謝の意を表します。

\section{参考文献}

1) 中央防災会議：東南海、南海地震等に関する専門調査会（第 16 回），参 考資料 2 強震動と津波の高さの検討に関寸る資料（平成 15 年 12 月 16 日） 2003.12

2) 長江拓也，鍾育霖，島田侑，福山國夫，梶原浩一，井上貴仁，中島正愛， 斉藤大樹, 北村春幸, 福和伸夫, 日高桃子：超高層建物の耐震性能を検 証する実架構実験システムの構築-E-ディフェンス振動台実験一, 日本建 築学会構造系論文集，第 640 号, pp.1163-1171，2009.6

3) 日本建築学会東海地震等巨大災害人の対応特別調査委員会 : 長周期地震 動と建築物の耐震性, 日本建築学会, 2007

4) 中央防災会議 : 南海トラフの巨大地震モデル検討会(第 15 回), 資料 1-1 南海トラフの巨大地震による震度分布・津波高について(第一次報告)(案) (平成 24 年 3 月 31 日)，巻末資料，2012.3

5) 山本優, 吉村智昭 : 3 次元大規模 FEM による東海・東南海・南海連動地 震の長周期地震動シミュレーション, 日本建築学会構造系論文集, 第 677 号, pp.1055-1064, 2012.7

6) 佐藤智美，大川出，佐藤俊明，藤堂正喜，西川孝夫：サイト固有の特性 を反映した経験式に基づく南海トラフ沿いの巨大地震に対する長周期地 震動予測, 日本建築学会構造系論文集, 第 695 号, pp.37-46, 2014.1

7) 北村春幸, 野村綾, 川崎恵, 壇一男, 佐藤俊明 : 長寿命鋼構造建物が遭 遇する複数の強震動を想定した累積損傷評価法の提案一名古屋三の丸地 区で想定される強振動を対象として一，日本建築学会構造系論文集，第 642 号, pp.1443-1452, 2009.8

8) 日本建築学会構造委員会長周期建物地震対応小委員会 : 長周期地震動と 超高層建物の対応策一専門家として知っておきたいこと一, 日本建築学 会, 2013

9）須賀貴之，佐藤克哉，木村暢志，北村春幸，山本優，木村雄一，青野英 志：最大応答值と累積值に着目した東海・東南海・南海三連動地震と単 独地震の対応関係, その 1 速度応答スペクトルとエネルギースペクトル による評価, 日本建築学会大会学術講演梗概集, 構造 II, pp.1051-1052, 2013.8

10) 佐藤克哉，木村暢志，北村春幸，佐藤利昭，木村雄一，青野英志，山本 優：単独地震を用いた東海・東南海・南海連動地震の最大応答值と累積 值の評価その $1 \sim 2$, 日本建築学会大会学術講演梗概集, 構造 II, pp.1007-1010, 2014.9

11) 秋山宏：エネルギーの釣合に基づく建築物の耐震設計，技報堂出版， 1999.11

12) 北村春幸 : 性能設計のため建築振動解析入門第二版，彰国社，2009.4

13) 秋山宏: 建築物の耐震極限設計, 財団法人東京大学出版会, 2000.7 


\title{
SEISMIC RESPONSE EVALUATION METHOD \\ FOR MAXIMUM RESPONSE AND CUMULATIVE DAMAGE OF HIGH-RISE BUILDING UNDER THE TOKAI-TONANKAI-NANKAI MULTI-SEGMENT EARTHQUAKE BASED ON THE RESPONSE OF THE EARTHQUAKES CONSTITUTING THE MULTI-SEGMENT EARTHQUAKE
}

\begin{abstract}
Masashi KIMURA *, Haruyuki KITAMURA **, Toshiaki SATO***, Yuichi KIMURA ****, Hideshi AONO ${ }^{* * * *}$ and Yu YAMAMOTO *****
\end{abstract}

\author{
* Graduate Student, Dept. of Architecture, Tokyo Univ. of Science. \\ ** Prof., Dept. of Architecture, Tokyo Univ. of Science, Dr. Eng. \\ *** Assist. Prof., Dept. of Architecture, Tokyo Univ. of Science, Dr. Eng. \\ **** Design and Proposal Division, Taisei Corporation, M. Eng. \\ ***** Technology Center, Taisei Corporation, Dr. Eng.
}

Historically, multi-segment megathrust earthquakes, such as the Tokai-Tonankai-Nankai earthquakes, have occurred repeatedly along the Nankai Trough. The next large earthquake along this trough is highly likely to occur in the near future. Multi-segment earthquakes produce numerous ground motion patterns because of differences in the orders and time intervals of the occurrences, even for a given earthquake source and rupture starting point. Understanding the responses of high-rise buildings to multi-segment earthquakes is complicated. In this study, the relationships between Tokai-Tonankai-Nankai multi-segment earthquakes and individual earthquakes were examined in the response spectra and energy spectra. On the basis of the relationships between the spectra, a seismic response evaluation method was developed for estimating the maximum response and cumulative damage that would occur to high-rise buildings in the event of a Tokai-Tonankai-Nankai multi-segment earthquake.

We use the ground motion of a Tokai-Tonankai-Nankai multi-segment earthquake estimated by Yamamoto and Yoshimura. This long-period ground motion was simulated using a three-dimensional (3D) subsurface ground model for the Kanto, Nobi, and Osaka plains. The predominant period of the multi-segment earthquake coincides with that of the greatest single earthquake experienced in the region. We referred to the predominant period of the greatest single earthquake the "specific period range" for each site, and we focused on this specific period range in this study. We determined the principal axis of the ground motion because of the necessity of considering the principal axis in evaluating the maximum response. When limited to the specific period range, the direction of the energy spectra is approximately the same as that of the response spectra. In this study, we examined the directions of energy spectra because their directions are clearer than those of response spectra.

Kitamura and others have studied the maximum response and cumulative damage that occur when multiple earthquakes occur individually or sequentially in intervals. In such a case, the maximum response depends on the greatest single earthquake, and the cumulative damage is expressed as the summation of the damage caused by multiple earthquakes. However, in the case of overlapping ground motions over short intervals, the maximum response may increase. By examining response spectra, we confirmed that a comparatively strong relationship exists between the square-root-of-sum-of-squares (SRSS) spectrum of individual earthquakes and a multi-segment earthquake spectrum. In contrast, in examining energy spectra, we found that a fairly strong relationship exists between the summation of individual earthquake spectra and a multi-segment earthquake spectrum.

We applied these relationships to the estimation of the seismic response of high-rise buildings. The maximum response produced by a multi-segment earthquake can be estimated by increasing the ground motion of the greatest single earthquake to the provisional multi-segment earthquake level based on an adjustment factor, termed " $a_{k}$ " in this study, before the seismic response analysis. This adjustment factor is the ratio of the greatest single earthquake spectrum to the SRSS spectrum of single earthquakes. The cumulative damage is estimated by summing the energy of individual earthquakes and applying the energy balance-based seismic response evaluation method. The results of the seismic response analysis conducted show that these estimations matched the responses produced by multi-segment earthquakes comparatively well. 